Portland State University

PDXScholar

$5-1973$

\title{
Counseling Problems that Accompany the Diagnosis of Mental Retardation
}

\author{
Betty Daggett \\ Portland State University \\ Shirley H. Durkheimer \\ Portland State University \\ Abigail M. Lawton \\ Portland State University
}

Follow this and additional works at: https://pdxscholar.library.pdx.edu/open_access_etds

Part of the Social Work Commons

Let us know how access to this document benefits you.

\section{Recommended Citation}

Daggett, Betty; Durkheimer, Shirley H.; and Lawton, Abigail M., "Counseling Problems that Accompany the Diagnosis of Mental Retardation" (1973). Dissertations and Theses. Paper 1606.

https://doi.org/10.15760/etd.1605

This Thesis is brought to you for free and open access. It has been accepted for inclusion in Dissertations and Theses by an authorized administrator of PDXScholar. Please contact us if we can make this document more accessible: pdxscholar@pdx.edu. 
ABSTRACT

This is a report of a descriptive study in which a random sample of fifty out of four hundred returned questionnaires from parents with a mentally retarded child were analyzed. The focl of analysis were: parental attitudes toward the child; (2) the changes experienced by the family as affected by birth order and sex of the mentally retarded child; (3) how the diagnosis was accomplished; and (4) how in their opinIon services during this diagnostic perlod could be 1mproved.

The data revealed that: (1) protectiveness toward the child is the predominant parental response; (2) negat1ve changes are probably twice as high with an only child who is retarded; (3) male retardates are somewhat more disruptive than are female; (4) diagnosis must be Individualized; however, generalizations which can be made include: understandable language, patience, empathy, and above all honesty . 


\title{
COUNSELING PROBLEMS THAT ACCOMPANY THE DIAGNOSIS OF MENTAL RETARDATION
}

\author{
by \\ BETTY DAGGETT \\ SHIRLEY H. DURKHEIMER \\ ABIGAIL M. LAWTON
}

A practicum submitted in partial fulfillment of the requirements for the degree of

MASTER OF SOCIAL WORK

Portland State University

1973 
TO THE OFFICE OF GRADUATE STUDIES:

The members of the Committee approve the practicum of Betty Daggett, Shirley H. Durkheimer, and Abiga11 M. Lawton presented May, 1973. 


\section{ACKNOWLEDGMENTS}

The authors of this report are indebted in particular to three professors without whose advice and counsel this study would not have been completed.

Above all, it is with deep appreclation and affection that we acknowledge the invaluable assistance of our advisor, Dr. Jack Hegrenes, Assistant Professor and Soclal Work Training Director of the Child Development and Rehabilitation Center, University of Oregon Medical School. Dr. Hegrenes was at all times avallable to us for consultation and guidance. It was he who 'suggested that we evaluate the results of this study, and it was his humor, patience, and encouragement that sustained us during the months of preparation.

It was at the inspiration of Dr. Robert Boyd, a psychologist at the Crippled Children's Division of the University of Oregon Medical School, that this descriptive study of parental attitudes was begun. He composed the questionnaire, and malled it to the potential sample. Throughout the preparation of this report, Dr. Boyd gave freely of his knowledge, experience, and time. We are most grateful to him. 
Our thanks also go to Dr. Quentin D. Clarkson, Associate Professor at Portland State University, for his assistance when problems arose concerning the coding and tabulation of the data. His help was cruclal to the continuance of the study and final evaluation.

Finally, in general, we are grateful to the parents who took the time to record their memories of a painful experience in order to help others. 
TABLE OF CONTENTS

PAGE

ACKNOWLEDGMENTS • . . . . . . . . . . • . . . 111

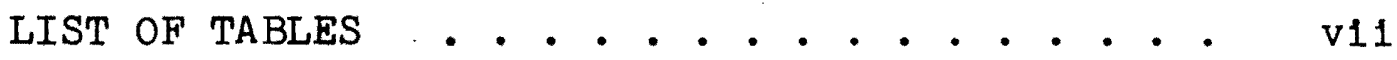

LIST OF FIGURES . . . . . . . . . . . . . . v111

INTRODUCTION . . . . . . . . . . . . . . $1 \mathrm{x}$

CHA PTER

I METHOD OF INQUIRY . . . . . . . . . . 1

Procedure for Obtaining the

Data............ . 1

Coding and Tabulation of Data . . 2

Problems of the Study . . . . . 2

II DESCRIPTION OF THE STUDY IN DETAIL . . 4

The Respondents . . . . . . . 4

The Mentally Retarded Ch1ld

(MRC) . . . . . . . . 5

Memory of Reaction . . . . . 5

The Advice Given . . . . . . . 11

To Whom Parents Turned For Help and Support . . . . . . 12

Attitudes of Parents Toward MRC

After Being Told . . . . . . 17

Effect of Sex on Parental

Attitudes Toward the MRC . . . 21

Effect of Blrth Order on Parental

Attitudes Toward the MRC . . . 22 
III CHANGES IN THE FAMILY . . . . . . 25

Changes in the Fam1ly with Regard to Sex of the MRC ..... 28

Changes in the Fam1ly W1th Regard to Birth order of the MRC . . 31

IV HOW PARENTS WERE TOLD -- HOW THEY WOULD LIKE TO BE TOLD . . . . . 34

Who Told Parents . . . . . 34

Characteristics of the Teller . . 34

The Advice Wanted -- What Would

Be Most Helpful ...... 44

$\mathrm{V}$ CONCLUSIONS • • • . . . . • • • 47

BIBLIOGRAPHY • • • . . . . . . . . . . . 49

APPENDIX - . . . . . . . . . . . . . 54

QUESTIONNA IRE . . . . . . . . . . . . . . 59 


\section{LIST OF TABLES}

TABLE

PAGE

I. MEMORY OF REACTION . . . . . . . . . . 7

II. TO WHOM PARENTS TURNED FOR SUPPORT . . . . 14

III. ATTITUDES OF PARENTS TOWARD MRC AFTER

BEING TOLD . . . . . . . . . . . 20

IV. CHANGES IN THE FAMILY . . . . . . . . . 26

V. MEAN PERCENTAGE OF ALL POSSIBLE POSITIVE

AND NEGATIVE CHANGES . . . . . . . 28

VI. THE EFFECT OF THE MRC'S SEX ON FAMILY INTEGRATION . . . . . . . . . . . 30

VII. PERCENTAGE OF POSITIVE AND NEGATIVE

CHANGES ACCORDING TO BIRTH ORDER

OF MRC . . . . . . . . . . . . . 33

VIII. WHAT WAS TYPICAL OF THE TELLER . . . . . . 40

IX. WHAT WAS DESIRED OF THE TELLER . . . . . . 42 


\section{LIST OF FIGURES}

FIGURE

PAGE

1. FATHERS' AGE ............ . 54

2. MOTHERS' AGE ............. 55

3. EDUCATION ............. . . 56

4. AVERAGE ANNUAL INCOME . . . . . . . . 57

5. LOCATION MOST OF MARRIED LIFE . . . . . 58 


\section{INTRODUCTION}

Every parent who has had a retarded child must at some point in time face the disappointment and sorrow that accompanies the discovery or the final confirmation of his suspicions. Whether the news comes at birth or is delayed until the early school years, the experience is extremely painful for the parents, and an exacting task for the person who must do the tell1ng.

In 1968 a descriptive study was undertaken to obtain parental perceptions and opinions regarding the manner in which they were first told of their child's mental retardation, the effects of this upon their attitudes toward the child, the changes experienced by the family, and finally how they were told and what they liked most and least about the teller. The purpose was to use this data in the curriculum for training medical students in counseling parents. Such information could also be useful to soclal workers, psychologists, special educators, or any professional who will be, or may be working with the families of retarded children. 


\section{CHAPTER I}

\section{METHOD OF INQUIRY}

An elght page questionnaire was constructed by professionals at the Crippled Children's Division of the University of Oregon Medical School. This was then tested on a small group of parents for additions and/or suggestions. It was decided to use some open-ended questions as well as those of an objective nature. Although the open-ended questions were seen as enabling a more exact account of the parents' attitudes, the objective form was necessary for later coding, managing and evaluating the data. Each of the open-ended questions was, however, duplicated as to general content by an objective question.

Procedure for Obtaining the Data

The original population was chosen from parents who belonged to the Multnomah County Assoclation of Retarded Children. Questionnaires were sent to all one hundred members. From this population there was a 50 per cent return. Following this the questionnaire form was changed slightly so as to include more demographic information. Eleven hundred questionnaires were then sent to Fairview, the oregon State Institu- 
tion for the Mentally Retarded. The return from this mallout was approximately 40 per cent.

For the analysis, a random sample of fifty completed questionnaires was chosen from those returned by the parents with children at Fairview.

Coding and Tabulation of Data

A coding sheet was devised and the coded information for each respondent was then punched on IBM cards. Due to the numerous cholces for some questions as well as the open-ended questions, not all answers could be coded, so some answers were tallied directly from the questionnaires.

Problems of the study

An institutionalized sample eliminated most or all of the retardates classified as educable, and consisted mainly of the trainable and severely retarded.

The use of a questionnaire method of inquiry in 1tself poses problems for the researchers. Wolfensberger (1967) has stated:

There are a number of difficulties with questionnaire and interview approaches to parental feelings. on a structured questionnaire, the parent may tend to answer only that which is asked and other feelings he may be aware of may thus not be recorded. With less structured interview materials, problems in classifying or interpreting responses increase . . . 
With both techniques one must remember that conflicts are likely to be and have been so strong, needs so urgent and repression so likely, that any verbal statement of parents regarding past and present findings cannot easily and forever be accepted at the manifest level. (p. 334)

Several other considerations need also be born in mind: (1) No independent information was avallable as to what the informing professional actually sald or did, (2) the 40 per cent who elected to answer this questionnalre may have had some prefudiclal reasons for responding, (3) there was no information about the 60 per cent who chose not to answer, and (4) quite apart from prejudicial motives, the ability and willingness of the parents in the sample to answer a long questionnalre about such a painful event sets them apart--one simply cannot assume them to be representative of parents of the retarded in general. Finally it must be noted that the data for this study was gathered in 1968; that five years have elapsed between the research and its evaluation. 
CHAPTER II

DESCRIPTION OF THE STUDY IN DETAIL

\section{The Respondents}

The questionnaires were fllled out by twenty-elght mothers ( 56 per cent), five fathers ( 10 per cent), and in sixteen cases by both (32 per cent). One didn't answer this question.

The age of the parents lay in the middle range, and in most instances both parents had completed high school. The range of education of the parents extended from less than grade elght to the completion of graduate school.

Fathers' occupations were well distributed: 18 per cent professional and technical, 10 per cent proprietors and managers, 4 per cent sales or clerical, 24 per cent skilled workers, 6 per cent unskilled, and 4 per cent were retired. Sixty-eight per cent of the mothers were homemakers.

Most families were in the middle income bracket: 48 per cent earned between $\$ 5,000$ and $\$ 10,000$ a year, and the resident location for these families ranged from a rural setting ( 16 per cent) to a city above 
100,000 (26 per cent). Demographic information in more detail is shown in figures in the Appendix.

The Mentally Retarded Child (MRC)

The sample contains thirty-five boys and fifteen girls who were born, for the most part, during the $1940^{\prime} \mathrm{s}$ and 1950's. Fifty per cent were diagnosed as mongolold, 44 per cent as a premature birth, and 6 per cent were hydrocephal1c. These diagnoses were made in 84 per cent of the cases under one year of age. Ninetytwo per cent of these children were initially or eventually institutionalized.

\section{Memory of Reaction}

There were nine possible responses to the question which asked for a description of the parents' memory of their reaction upon first being told of their child's retardation (see Questionna1re, item 12). Although there were not any formalized efforts to establish construct validity for these reactions, it was decided that two of the cholces could be seen as indicating reactions of "relief," one of "sadness," one of "guilt," two of "shock," two of "denial," and one of "anger." It is unfortunate that these emotions were not more evenly represented. 
The two most often checked responses (both with 42 per cent) fell under the categories of rellef ("I now knew that what I had suspicioned was true," "I was glad that someone finally told me"), and sadness, ("I just felt sad and miserable"). Following reactions were: guilt (22 per cent), shock (20 per cent), denial ( 6 per cent), and anger ( 2 per cent). Answers to this question could be checked singly or in any combination. Table I 1llustrates this breakdown as well as the total percentage checked in each category. Forty-six per cent of the sample checked only one answer, 32 per cent checked two responses, 8 per cent checked three categorles, and 14 per cent did not answer. 


\section{TABLE I}

MEMORY OF REACTION

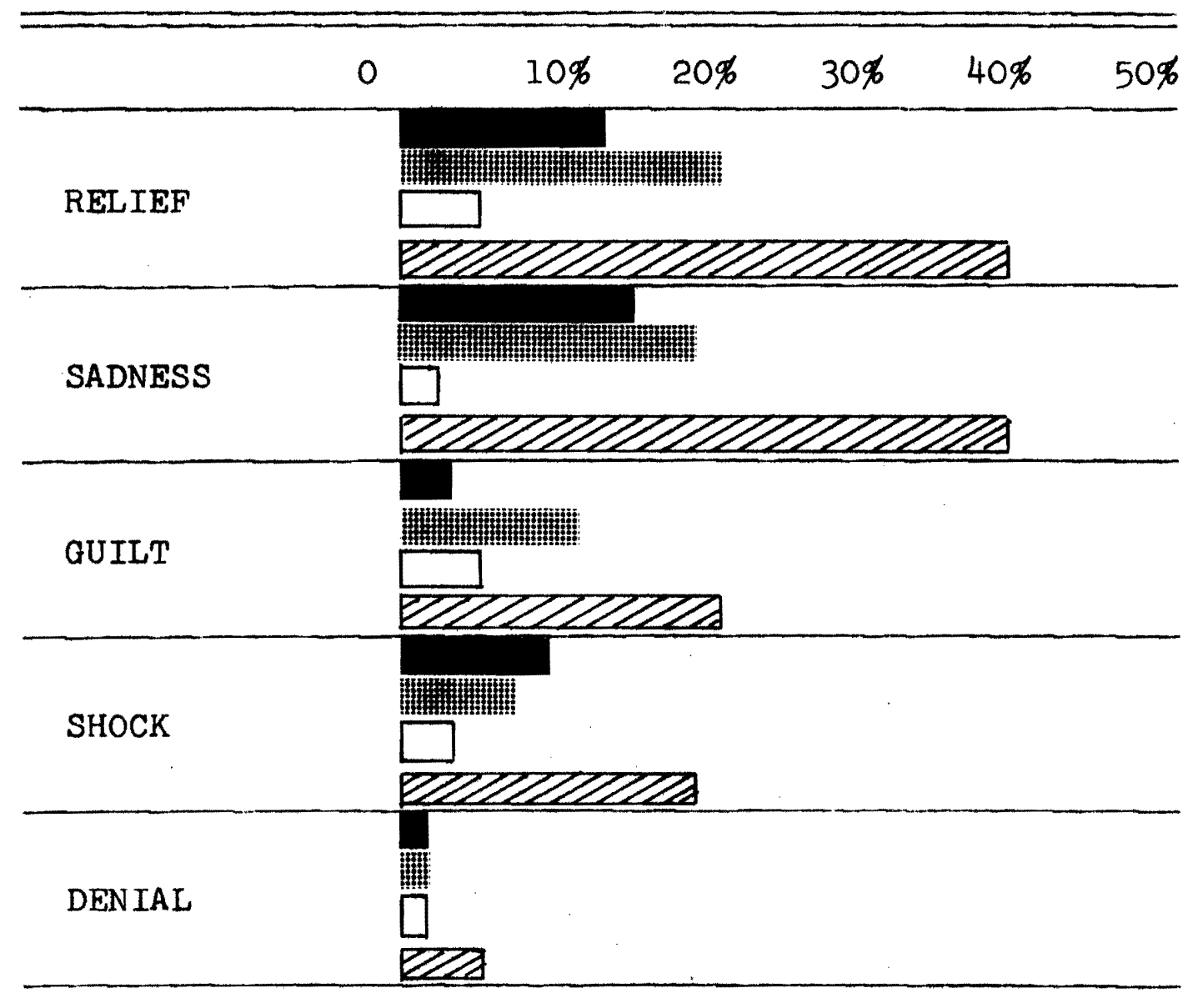

ANGER

檌

\section{目}

One

answer

Combined with two answers
Combined with three answers

Total percentage checked 
The range of feelings reported is noteworthy-there appears to be no one reaction that a professional could consistently count on. There is also wide agreement in the literature that the reactions to diagnosis are highly individualistic. (Begab, 1956; Cohen, 1962; Sch1ld, 1964; Wolfensberger, 1967)

The intensity of response and the manifestation of reaction vary widely within and between people depending on a variety of dynamic factors: individual personality, nature of the marital relationship, parental aspirations, feelings about deviancy, parental roles, socio-economic statuses, etc. (Sch11d, 1971, p. 434)

Describing this variety of response, schild notes that prominently mentioned reactions are guilt, amblvalence, disappointment, frustration, anger, shame, and sorrow.

Most often mentioned in the ilterature is the feeling of guilt, usually due to the fact that the parents do not feel for their child as they belleve they should. (Grebler, 1952; Hastings, 1948; Hersh, 1961; Zwerling, 1954) Wolfensberger (1967) however, considers possible benefits of parental guilt for the child via additional or stronger motivation to provide extra attention. He polnts out that little research has been done in the area of guilt. Recent writers seem to be more cautious about automatically assuming the universality of this reaction and have begun to 
stress other reactions. (Wolfensberger, p. 332) Patterson, a parent, thinks that "regret" might be a better term, particularly for the display of occasional negative behavior toward a retarded child. (Patterson, 1956) Only 22 per cent of these respondents indicated feeling guilty and one parent said,

we once had a psychologist at our school
who categorically stated that all parents
of retarded chlldren have guilt feelings.
This is nonsense! I don't feel guilty,
and in 14 years of meeting parents with
retarded children I have never met any
parents who felt guilty. Psycholcgists
and social workers who hamer on this
point are inclined to make us feel
guilty because we don't feel guilty.

Whether guilt was expressed or suppressed by the parents in this sample is academic--elght of the eleven who checked this response also remembered feeling sad and miserable.

Written comments from the parents indicate that emotions at this time were intense. One mother said, "The heartache was unbearable . . ." This study indicates that sorrow was one of the strongest reactions. It is well documented that though some emotions abate with time, not infrequently the grief, sorrow and mourning can be chronic or prolonged. (Beddie and Osmond, 1955; Cohen, 1962; Farber, 1960; Goodman, 1964; Olshansky, 1962; Owens, 1964; Roos, 1963; Soln1t and 
Stark, 1961; Thurston, 1960; T1sza, 1962) Bedd1e and Osmond liken the institutionalization of a retarded child to the death of that child, yet a death without proper rites. Thus mourning may be prolonged or delayed. Olshansky's proposal is that these parents suffer from a pervasive reaction he terms chronic sorrow, particularly when the child is severely impaired. He suggests that the parent finds it culturally unacceptable to express this pervasive grief and therefore attempts to deny his sorrow.

This tendency is often reinforced by the professional helper's habit of viewing chronic sorrow as a neurotic manifestation rather than as a natural and understandable response to a tragic fact. (p. 192)

Kanner (1953) considers the parents' prior emotional adjustment an important varlable when considering parental reactions:

Their own life experiences which have helped to shape their personalities, have contributed to the manner in which they adjust to the pleasant and unpleasant realities in general and to the presence of a handicapped child in particular. (Kanner, p. 232)

It can be noted, in summary, that these parents indicated a wide variety of reactions. Among these, the feelings of relief and sadness were predominant. These findings contrast somewhat from the literature 
which rarely mentions positive feelings and stresses guilt reactions. Professionals working with parents at this time should recognize the possibility of relief reactions along with feelings of grief and sorrow, and attempt to prepare parents for potentially reoccurring or sustained sadness.

\section{The Advice Given}

Parents indicated from a cholce of six possibilities what advice was given to them by professionals (see Questionnaire, item 9). Fifty-four per cent of the sample checked "Place child in an institution," 20 per cent were not advised at all ("none"); 12 per cent were told to "Go home and think about 1t"; 10 per cent checked. "Keep the child through early ch1ldhood and then place in an institution"; 8 per cent indicated "Other," w1thout further clarification; 6 per cent were advised to send their child to a speclal school; and 2 per cent were encouraged to "Keep the child indef1nitely." This data is consistent with the fact that 92 per cent of these children eventually ended up in an institution. Sixty-four per cent of the advice given implicated institutionalization. It must be kept in mind that this advice was given in the $1940^{\prime} \mathrm{s}$ and $1950^{\prime} \mathrm{s}$ and was, theref'ore, influenced by the theories 
of the times. It was more commonly felt, then, that retarded children almost invariably belonged in an institution where they could recelve expert help, be among their own kind, and not be damaging to the development of their normal siblings nor to the personal fulfillment of their parents. Today it is more widely recognized that this is not the simple issue that it was once thought to be and, while institutionalization is of value and/or necessary in some instances, the routine

ali or even most retarded children
alle
would frequently ignore both the wel-
fare of the child and the realities
of family relations. Such a practice
would, in addition, be economically
unfeasible. (Robinson and Robinson,
1965 , p. 524)

However, as Wolfensberger warns, "pro-institutional" vlews are now rarely seen in print, but traditional thinking has by no means died out. (Wolfensberger, 1967, p. 369)

\section{To Whom Parents Turned For Help and Support}

First knowledge of retardation represents a severe adjustment for parents in their expectations, hopes and plans for their child. The next section of this study addressed itself to the question of where parents find help and support. 
Parents could make any number of checks (see Questionnaire, 1tem 15), but for purposes of tabulation these were clustered into seven categories. Table II shows this breakdown. It was discovered that 62 per cent of the sample used a combination of sources, while 38 per cent used only one. 
TABLE II

TO WHOM PARENTS TURNED FOR SUPPORT

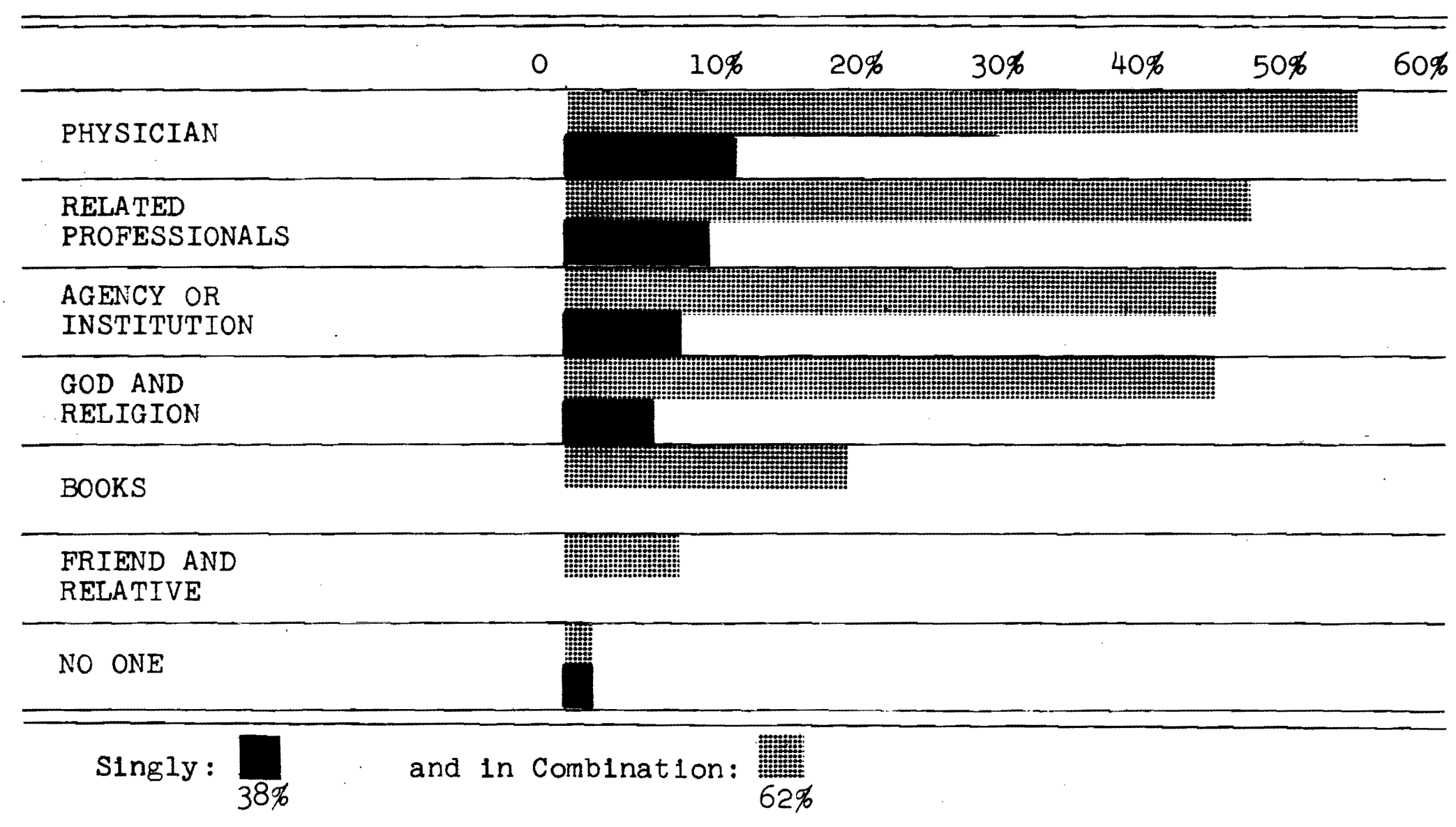


The most used source of support was the physician (56 per cent in combination, 12 per cent only, totaling 68 per cent). This could reflect the time lapse in the study as current increase in avallability of services In the area of mental retardation appears to lessen support on physiclans. Related professions such as a social worker, psychologist, public health nurse, etc., followed with a total of 58 per cent, ( 48 per cent in combination, 10 per cent only). Fifty-four per cent of these parents first turned to an institution or agency ( 46 per cent in combination, 8 per cent only). God and religion proved to be an important source of help for 52 per cent of the respondents ( 46 per cent in combination, 6 per cent only), and 20 per cent found books Important although they were always used supplementary to other supports. Only 8 per cent turned to friends and relatives, and two parents ( 4 per cent) checked "No one."

The data was also viewed from the perspective of "external" versus "Internal" sources of support. Regarded as "external" were sources which involved other people or organizations of a professional nature, while "Internal" was seen as anything distinctly personal or solitary. Ninety per cent of the respondents used external sources; 30 per cent of these used this 
type of help only. Ten per cent relied exclusively on internal sources for help, and this combined with the 60 per cent who used both types of support, showed that a majority (70 per cent) found internal types of help important. The fact that 52 per cent of these parents turned to religlous sources of help supports the many writers in the fleld who attest to the value and/or need of religion for parents faced with this crisis. (Boyd, 1951; Dybwad, 1964; Holt, 1958; Murray, 1959; Roos, 1963; Zwerling, 1954) of the twenty-six parents who checked either "God" or "minister, priest, or rabbi," fifteen, or 58 per cent of them, indicated, in a later question, that they were "closer together" as a family. This compares to 38 per cent who indicated this answer in the total sample. None of these twentysix respondents reported marital difficulties.

With regard to books, Wolfensberger points out that guided reading is one of the "least-exploited options in parent counselling." (p. 363) other writers as well have supported the 1dea that parents need, and can get from written material well grounded factual information about retardation and how others have experienced and coped constructively with this crisis. (Bhat1a, 1962; Schucman, 1963) Wolfensberger ends a very thorough discussion of what is sultable and 
avallable by strongly suggesting "that much more care and emphasis be placed on parental self-education via reading." (Wolfensberger, 1967, p. 363)

In general, then, 1t can be seen that although parents turn to the most obvious medical and professlonal sources of support at this cruclal time, many also make use of their connections with a church or minister. Professionals working with these parents might well make use of their less obviously related colleagues, and encourage the use of pertinent reading.

\section{Attitudes of Parents Toward}

MRC After Beling Told

A scale was developed to measure the following attitudinal clusters: (I) overprotection-take control, (2) Indulgence-feel sorry, (3) demanding-punitive, and (4) neglect-rejection. To obtain construct validity for this scale, a team consisting of a psychiatrist, a social worker, and two psychologists were asked to submit questionnaire items designed to reveal the attitudes listed above. The team submitted thirty-two 1tems to several graduate classes who decided which elght items would be used for the questionna1re. It should be cautioned that these are indicators of att1tudes, not actions. There was no way of confirming whether or not parents behaved in a manner consistent with their stated attitudes. 
The respondent was asked to check the two statements which came closest to describing his attitude (see Questionna1re, 1tem 21). The instructions were not always followed. Some checked none, others more than two, and some only one.

As it can be seen in Table III, the strongest response was to the att1tude of "need more protection" (27.06 per cent). This attitude is the most widely discussed parental response in the l1terature--one that until recently was seen almost entirely as harmful and indicative of underlying rejection. Waterman (1948) points out that sometimes overprotectiveness is a means of achieving satisfaction from the child. He describes a "martyr syndrome" in which the parents maintain some feeling of self-worth through extreme devotion to the needs of the retarded child. Roos (1963) softened this point of view by seeing it in terms of ambivalence, and Wolfensberger (1967) views it as almost a necessity, due to the prolonged dependency demands. "H1gh protectiveness may thus be an adaptive and desirable dynamic in the parent, especially the mother, rather than a pathogenic one." ( $p$. 345) There 1s, however, st1ll disagreement in this area.

For mothers who answered the questionnalre alone (56 per cent of the sample), "make most of his dec1- 
sions for him" and "felt sorry for him" came next, both with 15.9 per cent, followed by "feeling useless" and "take time to teach in order to prove to others he could learn," both with 13.5 per cent. These last two attitudes, according to the frame of reference described above, respectively imply a rejecting and demanding attitude. However, there was not one inc1dent when a mother checked both of these responses. Fathers alone (10 per cent of the sample) indlcated two prevalent and equal attitudes, "more protective" and "more flrm disclpline," both with 18.5 per cent. Th1s contrasts with the mothers' responses in which disclpline came next to last. Possibly this reflects the cultural tradition of mother in a nurturing role while father maintains a disclplinary role. Questionnalres which were fllled out by both parents (16 per cent) follow the pattern of responses made by the mothers alone falrly closely.

In summary, it can be noted that the most predom1nant parental attitude was protectiveness. The next two most important attitudes were "make decisions for hIm, "considered to be part of overprotectiveness, and "felt sorry," which is consistent with previously reported parental reactions. There seemed to be lower, 
but equal, inclinations to feel like withdrawing ("felt useless") and to be demanding ("teach").

\section{TABLE III}

ATTITUDE OF PARENTS TOWARD MRC

AFTER BEING TOLD

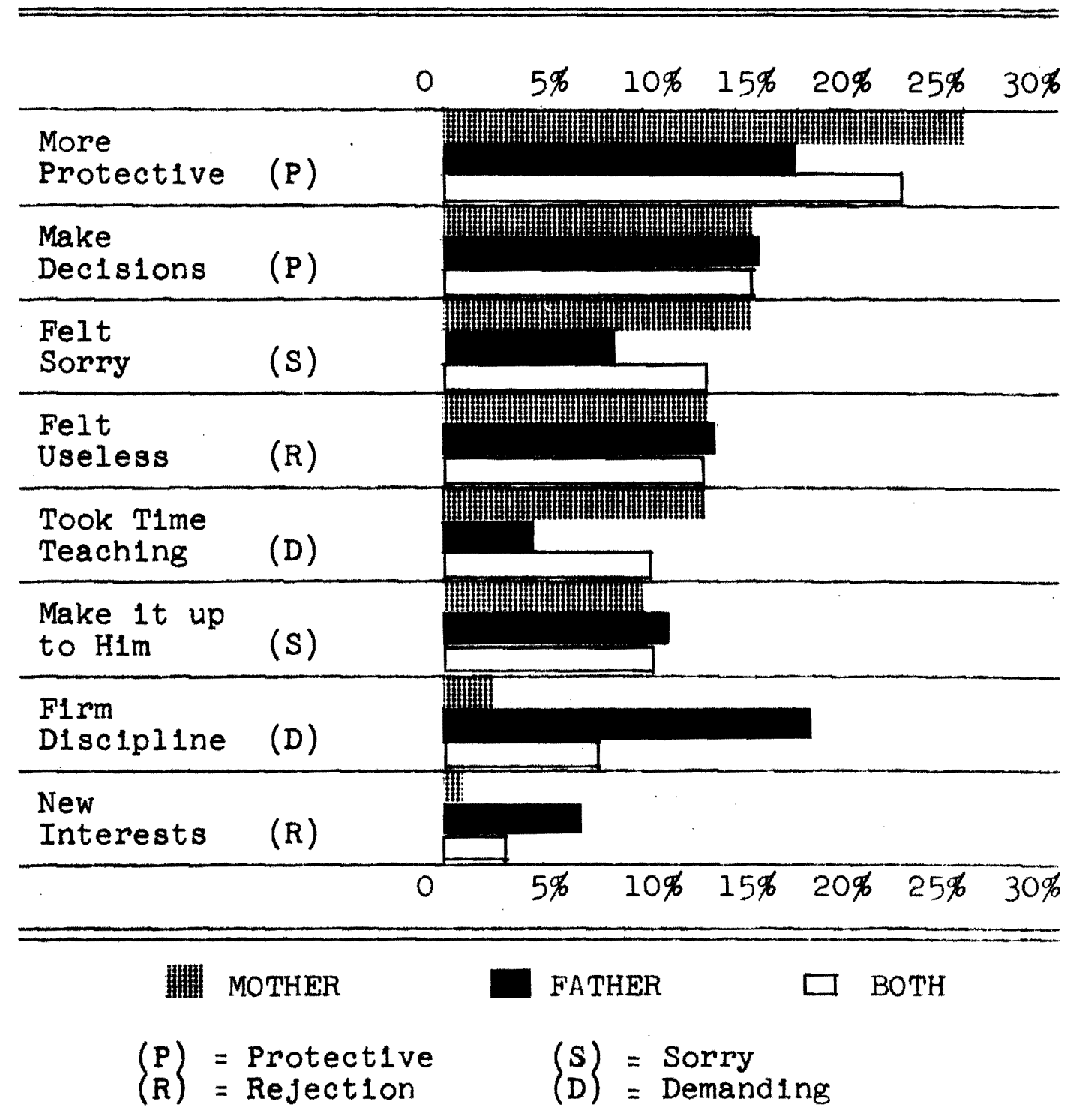


Effect of Sex on Parental

Att1tudes Toward the MRC

The dominant reaction of parents of the thirtyfive male retardates was "make decisions" for the child (19.3 per cent), followed by "more protect1ve" (15.7 per cent), "felt sorry" and "useless" (both 14.5 per cent), and "firm discipline" (11 per cent).

The responses given by the parents of the fifteen female retardates had "more protective" as the first in Importance (23.3 per cent) wh1ch was a good deal stronger than for males. Next was "felt sorry" (16.6 per cent), and third, all equal in occurrence, were four attitudes: "make 1t up to her," "take time to teach," "make decisions," and "useless," (all at 13.3 per cent). The parents of girls put discipline very low (3.3 per cent), and the rejecting attitude of "find new interests" was low for both boys and girls (3.7 per cent).

In general, then, it can be said that for this sample, the parents seemed to feel substantlally more protective of a girl. They also avold attitudes which imply discipline for a girl. If the child was a boy there seemed to be a greater tendency toward use of discipline and take control: 1.e., "make decisions for h1m." 
Effect of Birth Order on Parental

Att1tudes Toward the MRC

It was reasoned that the parental attitudes which have been discussed might vary predictably with the birth order of the retardate, and that such information could prove helpful to professionals in dealing with parents.

The data showed that feeling protective was low for the first child (15.6 per cent) in comparison to the mean response (21.6 per cent). It rose, however, if the retardate was second or third in the family (24.0 per cent and 24.9 per cent). Conversely, "make decisions" for the child decreased with more children, (first--18.7 per cent, second--16.0 per cent, third or more--10.7 per cent). These results are puzzling since this particular response ("make decision for him") had been postulated as part of the overprotective cluster. Indeed for the sample as a whole the two do tend to Increase together. However, in contrast to the total sample, when one focuses on birth order, the attitude cluster of protectiveness-take control (make decisions) seems to divide--1t increases for protectiveness, and decreases for control. It could be that with other older siblings present, responsibility is less concentrated, or there may simply be too many decisions and tasks and too little time. 
Feeling sorry and feeling indulgent both rise markedly when the retardate is placed third or more in the family. For the first and second born 12.4 per cent and 10.0 per cent respectively checked "felt sorry," but 24.9 per cent of the parents checked this response if the child was born third or later in the family. Similarly, the desire to "make it up to him" substantially increased as the retardate was preceded by more normal slblings (f1rst-born--9.3 per cent, second--8.0 per cent, third or more--17.5 per cent). It is interesting to note that both these attitudes decreased slightly when the retardate was second born, and then rose markedly if the child was placed third or more in the family. It is difficult from this study to make any hypothesis regarding this finding, but it can be sald that since both these responses were in the Indulgent-sorry cluster, the likelihood of these att1tudes increases considerably when the retardate has two or more older siblings.

Lastly, the more demanding-punitive att1tude ind1cated by checking "I wanted to spend extra time teachIng him in order to prove to others that he could learn" was comparatively higher for the f1rst-born (18.4 per cent). It was 12 per cent for the second born, and zero for a child placed third or later. It 
seems that parents tended to be more demanding--to have a greater desire to change the condition of their child if he occupled a more significant position in the family. "Entirely different parental dynamics are operant during the first creation of a child than in later ones." (Wolfensberger, 1967, p. 346) When the retardate had older siblings, it could be that many parental expectations, hopes and meanings had already been satisfied.

In summary, these results indicate when the retardate was the first child, the parent was inclined toward a high degree of involvement. The strongest emphasis was on making decisions for the child and taking time to teach him. These attitudes became more insignificant and in some cases disappeared if the retardate was third or more in the family, and were replaced by the attitudes of feeling more protective and sorry for the child. 


\section{CHAPTER III}

\section{CHANGES IN THE FAMILY}

To indicate changes which occurred to the family following the knowledge of retardation, parents could check any of twelve 1tems (see Questionna1re, 1tem 20). As 1llustrated in Table IV, four of these were viewed as positive, and eight as negative. It can be seen that the strongest positive responses were "closer together," (38 per cent), and "better and stronger persons," ( 36 per cent), while the most often occurring negative responses involved marital difficulties (28 per cent), decreased social life (30 per cent), Increased cost ( 30 per cent), and even more often, "fearful of more children," (36 per cent). 
TABLE IV

CHANGES IN THE FAMILY

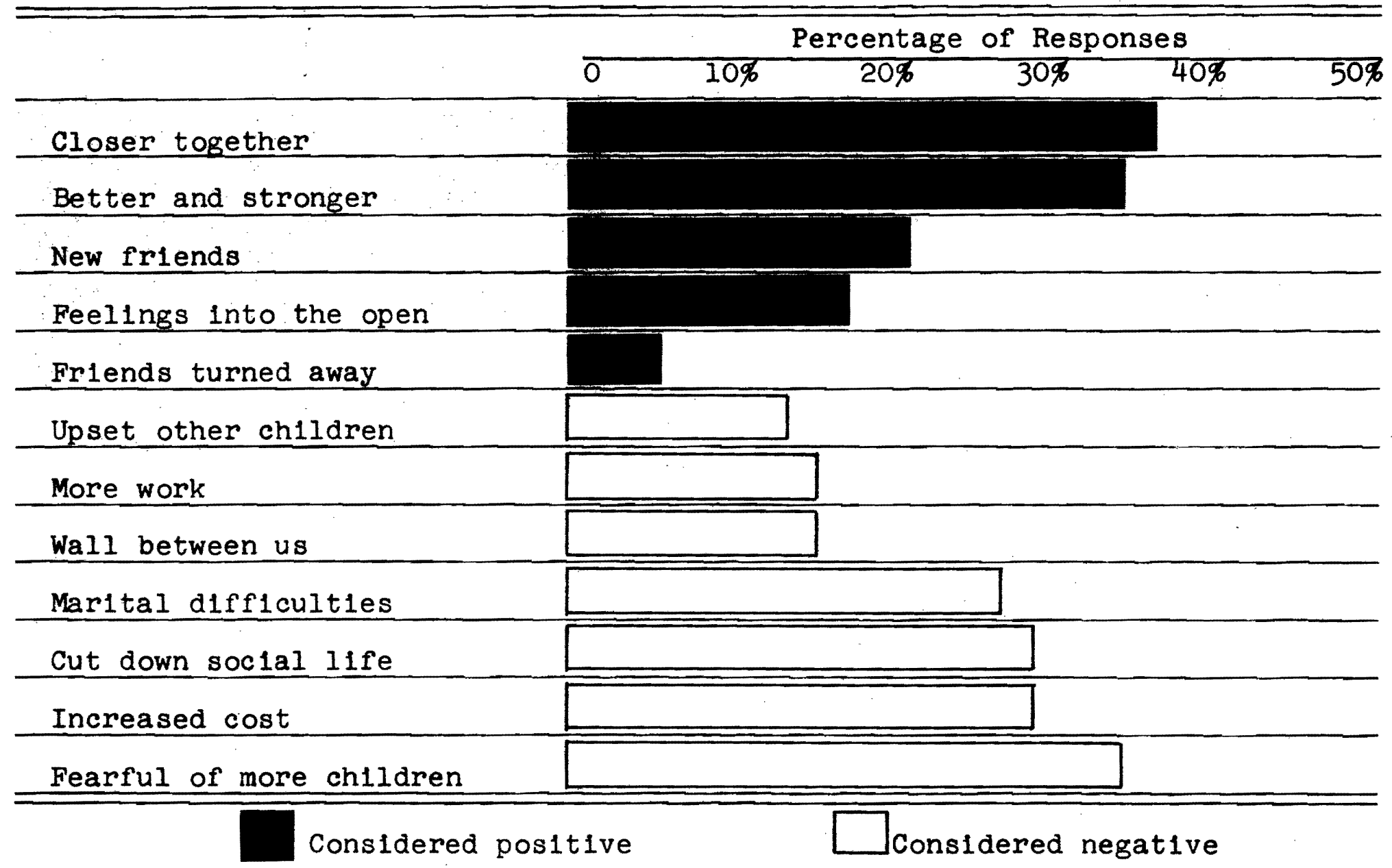


Almost half ( 48 per cent) of the parents in this study checked both positive and negat1ve changes; 26 per cent indicated only negative changes; 12 per cent reported only positive changes, and 14 per cent did not answer the question. Though it might be reasonable to assume that most commonly a family would experience both positive and negative effects, the results of this study in all likelihood reflect a cognitive dissonance resolution process in which a softening of effects takes place over time. Sixty per cent of the parents in this study reported positive changes of some sort, and this is similar to Kramm's (1963) findings in his study of families with a mongolold child. He found that after an initial negative reaction (the first six to ten years) 70 per cent of the parents in his study saw their retarded child as having been good and/or strengthening for them.

On the other hand, it can also be pointed out that although 26 per cent of the parents in this study indicated only negative effects, several of these same negative results are common to parenthood in general, and there is no way of knowing how these parents would have adjusted to a normal child. 
Changes in the Family With

Regard to sex of the MRC

Male retardates were shown to have a somewhat greater impact on changes in the family than females, both positive and negative, as can be seen in Table V. It also can be noted that in general more positive than negative changes were reported, though negative results did appear more pronounced for a male child.

TABLE V

MEAN PERCENTAGE OF ALL POSSIBLE POSITIVE AND NEGATIVE CHANGES

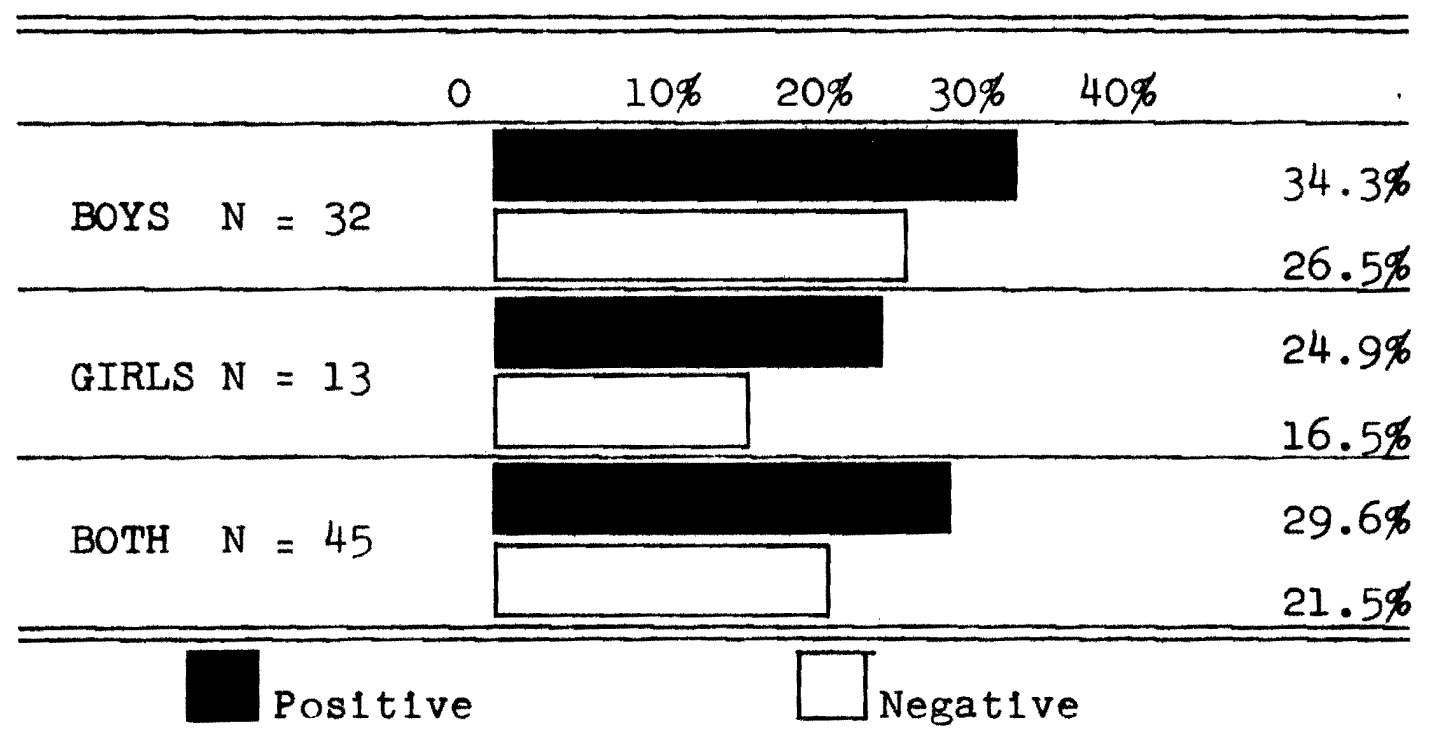

Table VI shows these reactions in more deta1l, and 1t is interesting to see that although parents of elther boys or girls scored almost equally on "marital difflculties," parents of girls checked "closer together" 46.1 per cent of the time, and zero on "wal1 
between us," In comparison to parents of boys who scored 40.1 per cent and 25.0 per cent respectively. This would seem to conform to Farber's (1959-1960) findings that boys tend to be more disruptive of marital integration than do girls. Farber stated, however, that this difference was not evident if the child was institutionalized. The present data does not indicate how long the children had been kept at home prior to institutionalization. 
TABTR VI

THE EFFECT OF THE MRC'S SEX ON FAMILY INTEGRATION

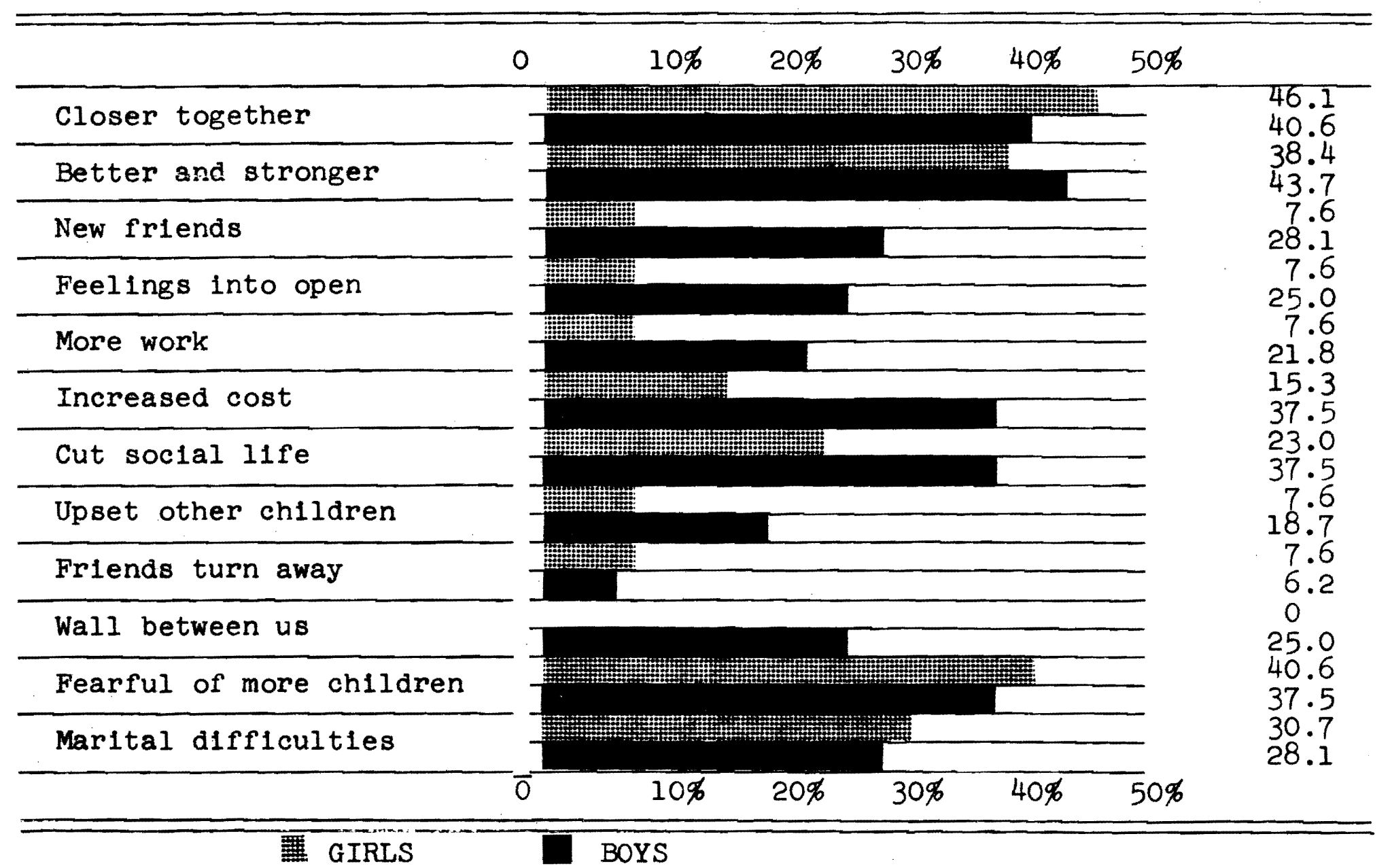


Cultural expectations could be influential here. It is more commonly acceptable for females to achleve less and be dependent, while males are expected to carry on family traditions and be the breadwinner. Begab (1963) theorized that, at least in lower class families, retardation may not be as tolerable among boys as among girls where boys are seen as future providers.

It can be sald, however, that in general these families had more adjustments to deal with if their child was a boy.

Changes in the Family with Regard to Birth Order of the MRC

Percentages for the following results lllustrated in Table VII, as well as those reported in Table VI, were arrived at by comparing the number of actual responses given to the total number of possible responses, elther positive or negative, for any given grouping, 1.e., males, females, first-born, etc. Table VII 1llustrates that the order of the retardate only seems to be significant if the child was an only child. For an only child, negative changes were reported almost twice as often as positive ones (27.5 per cent to 15 per cent). In all other instances the reported negative changes remalned remarkably con- 
stant, though positive changes seem to rise slightly as there are more normal siblings.

Surprisingly little has been sald, and virtually nothing done, regarding mental retardation in the first-born or only child as compared with families where the retardate is younger or has younger siblings. (Wol fensberger, 1967, p. 346)

Kramm's study (1963) did find discontent highest in familles whose first-born was retarded. It could be, however, that in the present study the time lapse between the event and 1ts report could have erased the differences that may have existed.

For the family with an only child who is retarded this data would indicate that the plcture is bleak indeed. This is most probably due to the almost complete frustration of many meanings or expectancies derlved from parenthood. Some of these listed by Ryckman and Henderson (1965) are: (1) the child as a physical and psychological extension of self; (2) as vicarious satisfaction; (3) as a measure of immortality; (4) as a personallzed love object; and (5) as enhancement of self-worth.

B1rth order, therefore, seemed to be an important varlable only if the child was an only chlld. Negative changes in this case were predominant. This might 
point to the encouragement of families with retardates as the first-born to have more children barring genetic limitations.

\section{TABLE VII}

PERCENTAGE OF POSITIVE AND NEGATIVE CHANGES ACCORDING TO THE BIRTH ORDER OF THE MRC

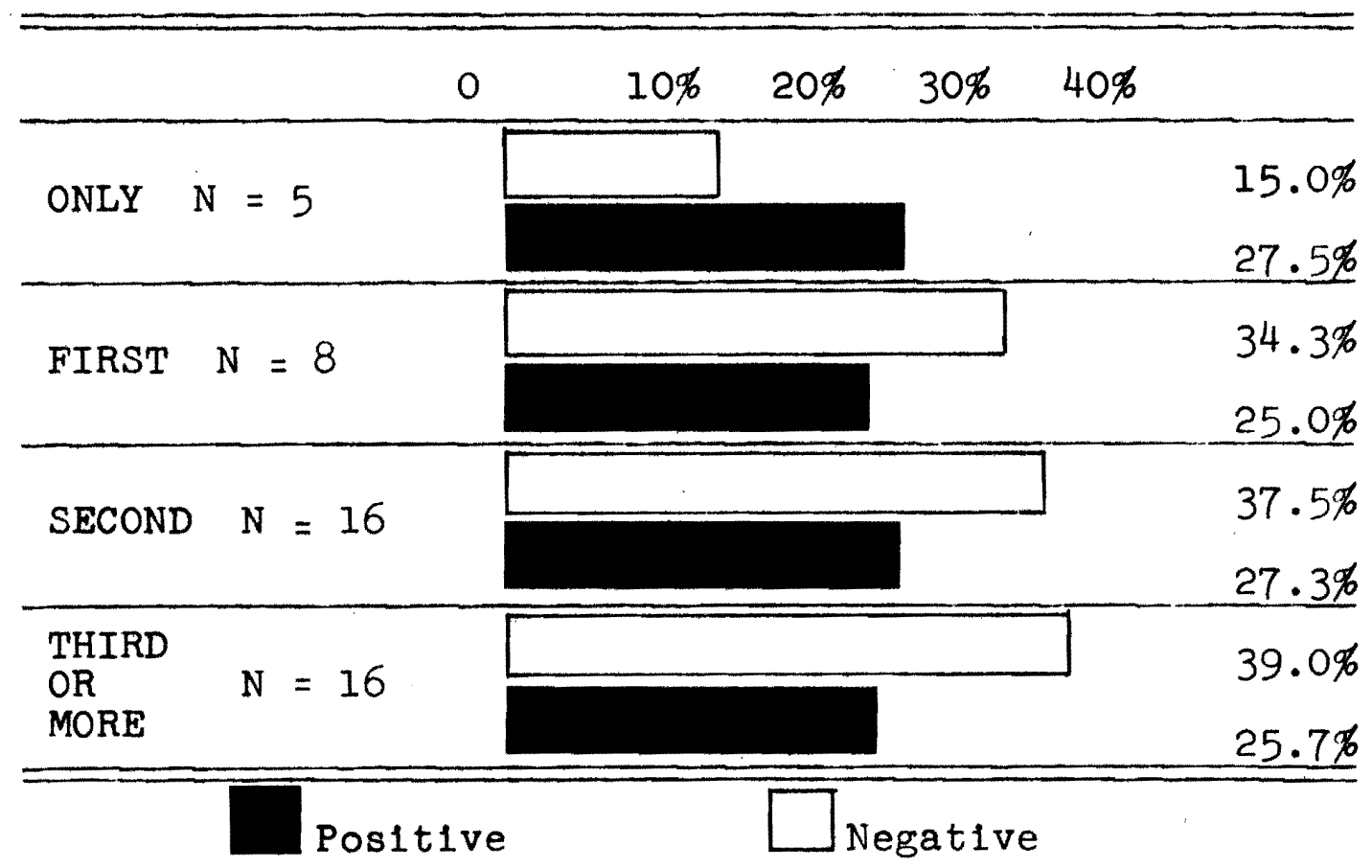


Who Told Parents

Item 6 of the Questionnaire asked parents: "Who first told you that your child was retarded?" As would be expected, a physician told most of the parents $(74$ per cent), followed by 8 per cent who checked "other," 6 per cent by a psychologist, 4 per cent by a social worker, 2 per cent by a teacher, and 6 per cent did not answer.

Characteristics of the Teller

Sixteen characteristics of a teller were listed in Questionnaire 1 tems 16 and 17, and parents were asked to first check what was typical of their experience and then check what they would like most and least about a teller. Table VIII 1llustrates what parents reported as having been typical, and of those who experlenced each characteristic, what percentage of them liked or disliked that characteristic. Table IX deplcts these same characteristics from a theoretical viewpolnt of preferences, and shows the five most and least desired characteristics. 
It is clear that of all the characteristics desired, "Gives information objectively and factually," with 82 per cent, was favored. Th1s was experienced by 54 per cent of the sample and of these, all liked 1t, none disliked 1t. One parent commented:

Would prefer to tell the exact truth to parents so they could make future plans for their child. Avold vague statements which would build up false hopes and maybe delay what treatment could be given.

Second in preference w1th 62 per cent of the sample was "Appear comfortable talking to us." This was experienced by 32 per cent of the parents, and of these, 26 per cent liked it and none disliked it. One parent who obviously had not experlenced this wrote:

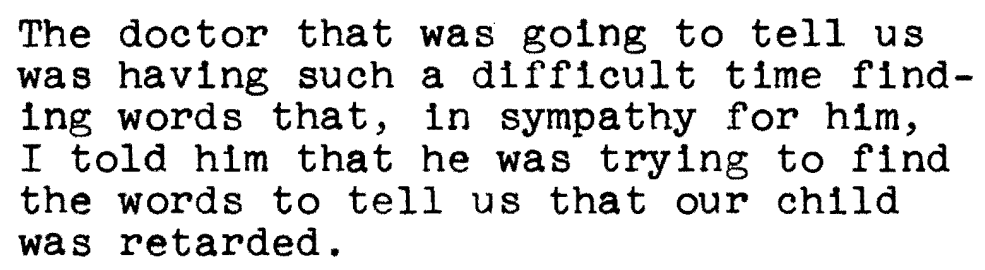

Th1rd of the most desired characteristics, w1th 58 per cent, was "Gives specific advice." Th1rty-two per cent of the parents experienced this, and of these, 28 per cent liked it and 6 per cent disliked 1 t.

"Appears to understand our problems" rated fourth in importance--44 per cent checked wanting th1s, and 38 per cent indlcated this as actually having happened. 
of these, 20 per cent liked 1t, and 4 per cent did not. Parents seemed to prefer this to "Expressed sympathy," though they were rated quite closely. It is possible that parents themselves distinguish between "understanding," and "sympathy"--a somewhat loaded word. One parent clarified: "I feel compassion and pity should be kept separate. If the doctor "feels sorry" for the parents, they too w1ll likely indulge in selfpity . . ."

Two characteristics rated equally for the fifth most desired characteristic. Forty per cent checked both "Takes a lot of time" and "Impresses us with the seriousness of the situation." Twenty-six per cent and 28 per cent respectively experienced the two, and 16 per cent in both cases reported liking these while none checked dislike. The former finding is supported by 1tem 14 of the Questionnaire in which 84 per cent of the respondents indicated a desire for more than one appointment. The necessity for more than one contact concerning diagnosis has been strongly emphasized in much of the 11terature. Waskow1tz (1959) stressed the fact that parents need time to absorb the meaning and extent of their problem. Hersh wrote: "In our experlence 'one-shot' evaluations are of little value." (Hersh, 1961, p. 61) And Llewellyn (1962) stated that 
the accomplishment of parental acceptance is not ever possible in one interview, or even a few. Parents, like chlldren, must go through a developmental process. Finally Caldwell, Manley and Seelye (1961) found in their study that a higher number of clinic contacts was assoclated with higher degrees of parental satisfaction. One parent in the present study summed up:

The true facts. NO generalities. A return visit or several after the initial shock has worn off to ask questions and recelve factual answers; places to turn to for advice and information. Also personal counseling in the home would be most helpful.

In general, it should be observed that the tellers here reported, for the most part, performed a difficult task quite well. Only two 1tems show obvious discrepancies: "Left decision up to us" was experienced quite frequently, and this was not among the most desired characteristics, and "Took a lot of time" was not as frequently experienced though it was among the most desired.

Turning now to the negative, the following are the five characteristics that parents liked least:

"Seems busy and in a hurry" (84 per cent), (2) "Uses a lot of big words" (78 per cent), (3) "Talks 'down' to parents (76 per cent), (4) "Appears unconcerned about our feelings" (70 per cent), and with less than a 
majority (5) "Does most of the talking" (40 per cent). These results compare favorably to the parents' reported experlence in that these five characteristics were rated among the lowest (see Table IX). Most tellers were evidently sensitive and aware enough to avold most of the undesirable methods.

It was clear, however, from the written comments, that in some instances the tellers were far too abrupt, even callous:

The doctor was completely indifferent, in a hurry, and of fered no understanding or advice for the future. He told me that he (the child) was a mongolold and that he would only be a vegetable.

And another:

It was late at night--that is, about 10:30 p.m., when he came to my hospital room and said: "Your child is a mongolian ldiot." He then turned away and left the room immediately.

The preceding data substantiates what has been well documented in the 11terature (Ehlers, 1962; Koch, Graliker, Sands, et.al, 1959; Mandelbaum and Wheeler, 1960; McIntire and Klekhaefer, 1963; Rheingold, 1945)-that the way in which parents are told is as important as what they are told.

Parents in this study gave a clear mandate to professionals to try to give this difficult information objectively and factually; to try to appear comfortable 
talking about these matters; to offer some specific advice and understand their problems, and be willing to take time to "work through" these things. They want professionals to avold being busy and in a hurry; using b1g, hard to understand words; talking down to them or not giving them a chance to talk, and being unconcerned or unsympathet1c. 
TABLE VIII

WHAT WAS TYPICAL OF THE TELLER

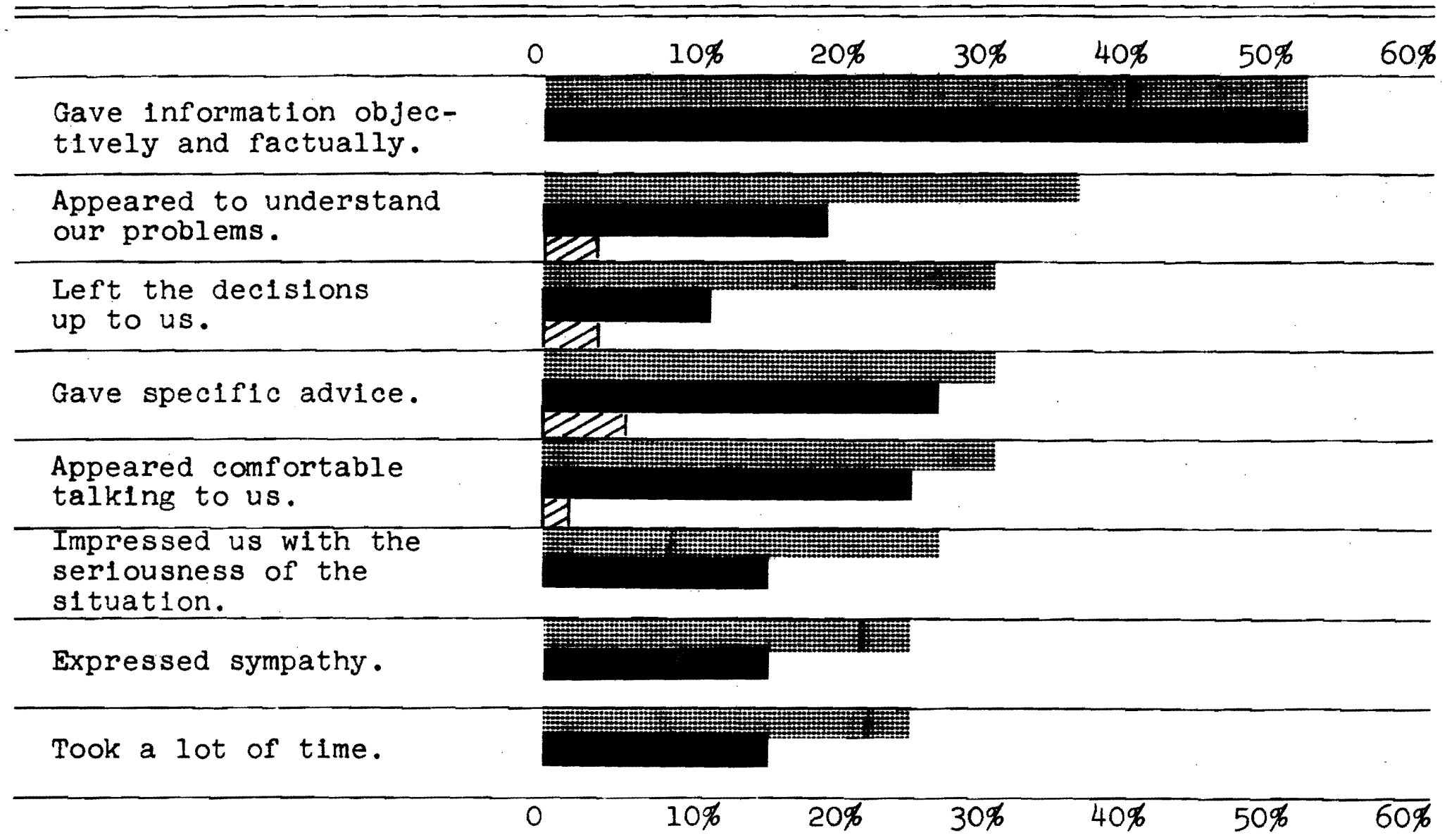


TABLE VIII--Continued

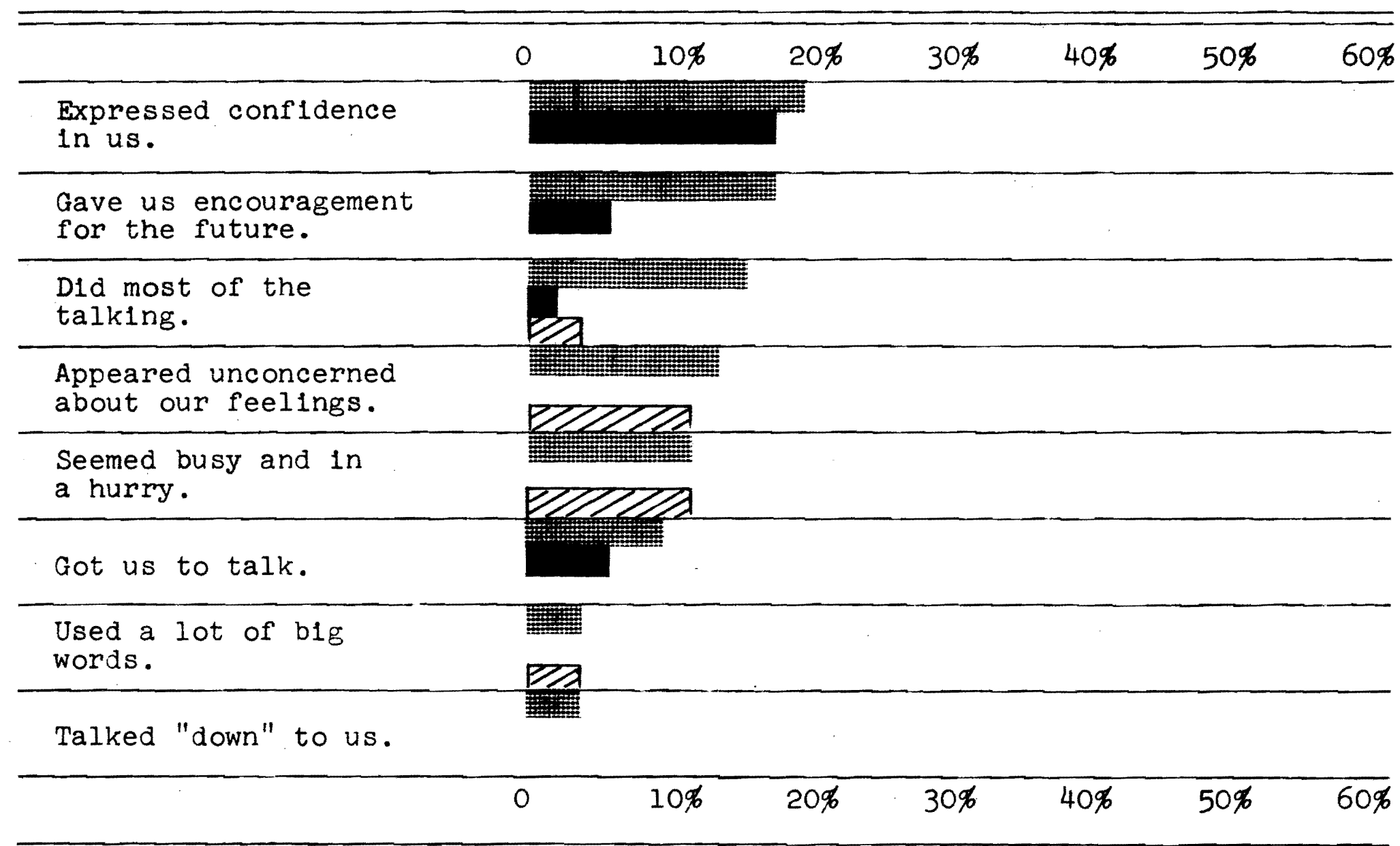

Typical

Liked

Disliked 
TABLE IX

WHAT WAS DESIRED OF THE TELLER

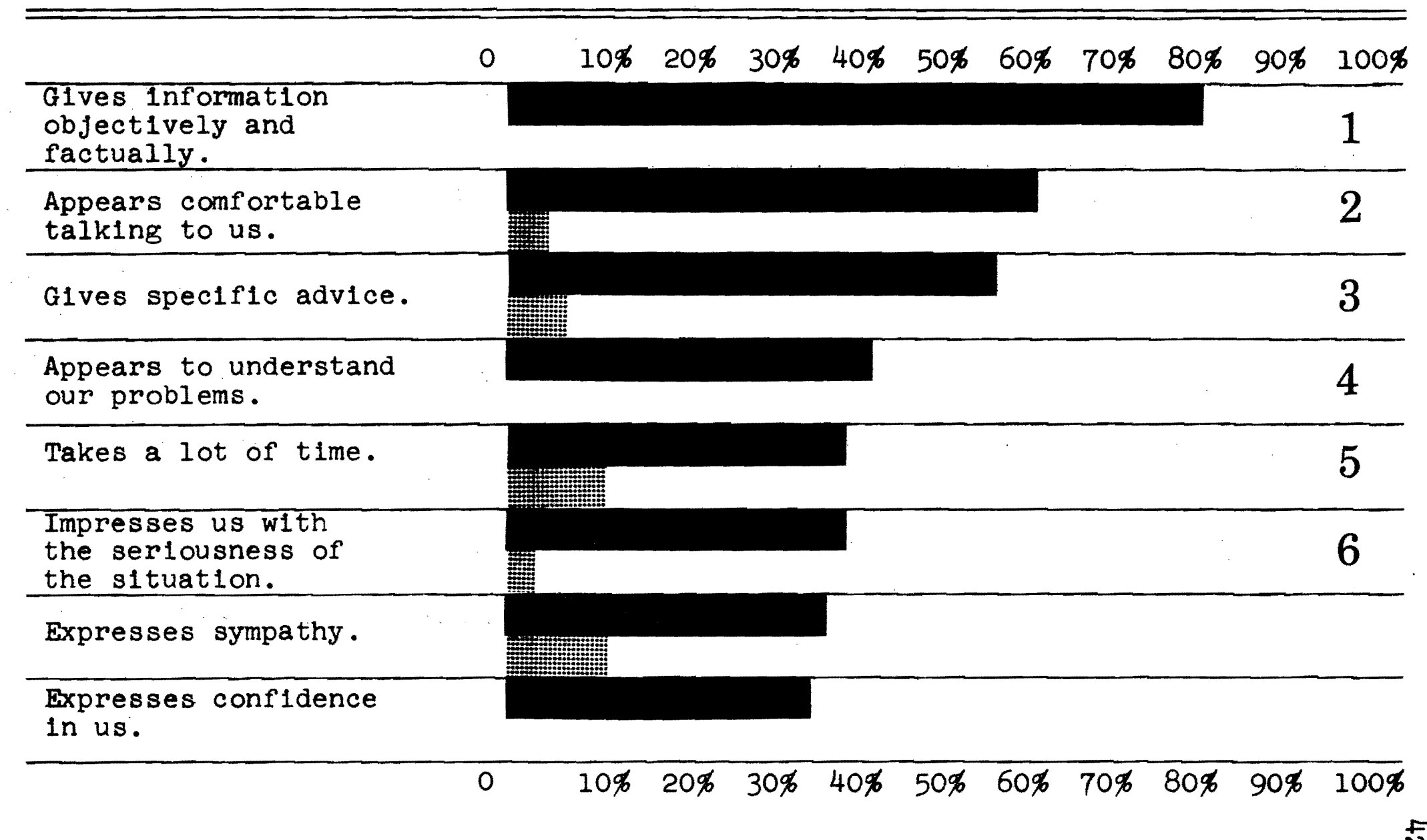


TABLE IX--Cont1nued

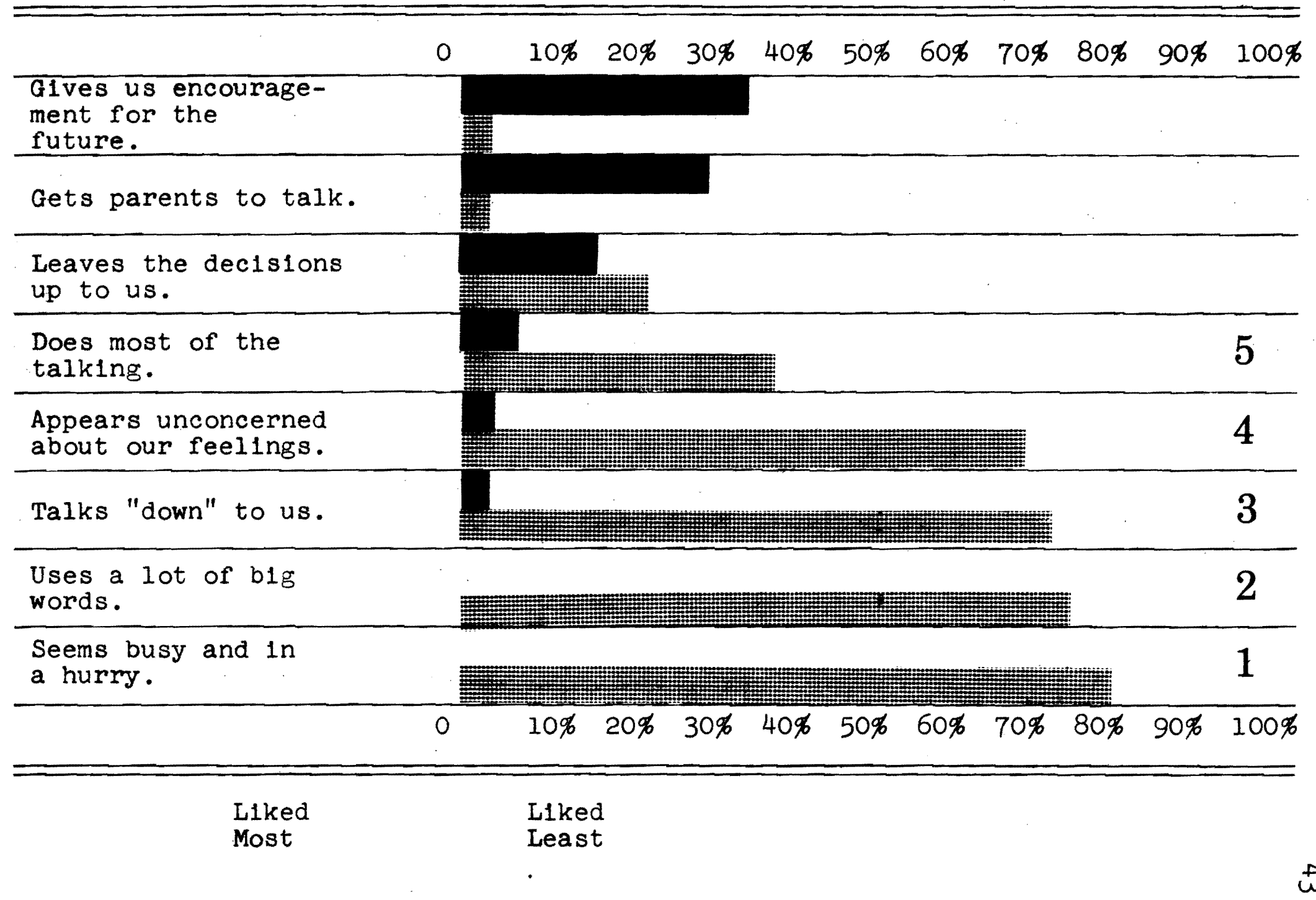


The Adv1ce Wanted--What Would

Be Most Helpful

In 1 tem 22 of the Questionna1re parents were asked to assume that they had the responsibility for informing someone of their child's retardation, and what they felt would be helpful to them in that first interview. Six cholces were ava1lable. In order of preference, the responses were: 46 per cent--"Sympathy and understanding"; 40 per cent--"Advice regarding school or training facilities in the community"; 36 per cent-"General description of the child's condition without specific advice"; 30 per cent--"Advice regarding managing (training) the child at home"; 28 per cent--"Advice regarding placing the child outslde of the home." No one checked, "Reassurance that it will probably be all right." These findings seem consistent with previous ones which stressed understanding and information.

In the open-ended questions, parents elaborated: "Know what you're talking about--don't give half-facts, allusions, etc."; "Tell parents what to expect from their child"; "Do not give advice, only information (especially doctors!)"; "Take time with family and take time for future calls"; "Direct parents immediately to other parents who have weathered this crisis"; "Develop some guidelines for telling relatives, friends, etc. Help parents know what to say and how to say 1t." 
Concerning this 1dea Sheimo (1959) points out that pressures created by the attitudes from other children, nelghbors and family toward the defective child and his parents can so exacerbate existing inner turmoll and dissatisfaction that there are times when to concentrate attention on the retarded child rather than on the parental conflict is "attempting to deal with the least relevant factor in the total situation." (p. 47) In addition: "Give compassion, knowledge, and direction"; "Memorize Simon Olshansky's article on 'Chronic Sorrow' . . and use 1t" (from an informed parent!); and finally, "Tell it like it is, giving time for parents to absorb. Sympathy and understanding, and then help parents plan what should be done."

As can be seen, the parents had a great varlety of suggestions. This variety points out the need for considerable individualization on the part of the professlonals (Chamberla1n, 1963; Kelman, 1953; Mahoney, 1958; She1mo, 1951; Waskow1tz, 1959; Zwerl1ng, 1954. It is also important to keep in mind that one cannot talk to a Ph.D. as if he were a high school student. Parents present a wide range of capac1ties for accepting and understanding the doctor's discussion . . . no single formulation of content can hope to serve so varied a population. (Zwerling, 1954) 
Outside of careful and even arduous listening, the professional should perhaps consider the simple process of asking parents at this time what would be most helpful to them. 


\section{CHAPTER V}

\section{CONCLUSIONS}

Some effects of having a retarded child upon a famliy and the manner in which parents experienced professional involvement have been discussed in detall. The main areas of consideration for counselors in the fleld are these:

\section{Effects on the Family}

1. The initial reactions tend to be relief at finally knowing, as well as sadness and misery.

2. Religion appears to be an integrating source of support.

3. The general parental reaction tends to be protective. Counselors could help parents use this natural feeling constructively.

4. More negative effects appear to be experienced if the retardate is a male or an only child.

Destred of the Professional

1. Give information objectively and factually.

2. Appear comfortable with the parents.

3. Give specific advice when indicated. 
4. Show empathy for their situation and confidence in their ability.

5. Offer continued contact.

Although more research is needed to enable a professional to effectively individualize his involvement, these findings support Waskowitz (1959, p. 324) who stated:

A few generalities can be made, namely, that parents would want to be handled gently and warmly at all times, in language that they can understand, without evasiveness, after thorough examination and, with enough time to digest the significance of such important material. 


\section{BIBLIOGRAPHY}

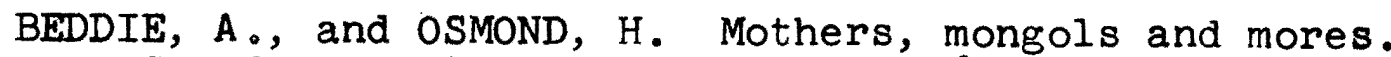
Canad. Med. Ass. J., 1955, 73, 167-170.

BEGAB, M. J. Factors in counseling parents of retarded children. Amer. J. ment. Defic., 1956, 60, 515524 .

- The mentally retarded child: A guide to services of social agencles. Washington, D.C.: U.S. Government Printing of fice, 1963.

BHATIA, B. D. Education and guidance of parents of the mentally retarded. Ch1ldren, 1962, 9, 21-25.

BOYD, D. The three stages in the growth of a parent of a mentally retarded child. Amer. J.ment. Defic., $1951,55,608-611$.

CALDWELL, BETTYY M., MANLEY, E. J., and SEELYE, BARBARA $J$. Factors assoclated with parental reaction to a clinic for retarded children, Amer. J. ment. Defic., 1961, 65, 590-594.

CHAMBERLAIN, E. R. Maximizing treatment suseptibility during the diagnostic process. Slow Learning Ch1ld, 1963, 10, 32-37.

COHEN, PAULINE C. The impact of the handicapped child on the family, Soc. Casewk., 1962, 43, 137-142.

DYBWAD, G. Group approaches and working with parents of the retarded: An overview. In Challenges in mental retardation. New York: Columbia Univers1ty Press, 1964, 41-52.

EHLERS, W. H. The moderately and severely retarded child: Maternal perceptions of retardation and subsequent seeking and using services rendered by a community agency. Doctoral Dissertation. Brandels University, 1962.

FARBER, B. Effects of a severely mentally retarded child on family integration. Monogr. Soc. Res. Chld. Devlpm., 1959, 24, No. 2. 
- Family organization in crisis: Maintenance of integration in families with a severely mentally retarded chlld. Monogr. Soc. Res. Chld. Devlpm., 1960,25 , No. 1

GOODMAN, L. Continuing treatment of parents with congenitally defective infants. Soc. Wk., 1964, 9 (1), 92-97.

GREBLER, ANNE MARIE. Parental attitudes toward mentally retarded children. Amer. J. ment. Def1c., 1952, $56,475-483$.

HASTINGS, D. Some psychlatric problems of mental def1clency. Amer. J. ment. Def1c., 1948, 52, 260-262.

HERSH, A. Casework with parents of retarded children. Soc. Wk., 1961, 6, 61-66.

HOLT, K. S. Home care of severely retarded children. Pediatrics, 1958, 22, 744-755.

KANNER, L. Parents' feelings about retarded children. Amer. J. ment. Def1c., 1953, 57, 375-383.

KELMAN, H. R. Parent guidance in a clinic for mentally retarded children. J.Soc. Wk., 1953, 34, 441447 .

KOCH, R., GRALIKER, BETTY V., SANDS, R., and PARMELEE, A. H. Attitude study of parents with mentally retarded children: I. Evaluation of parental satisfaction with medical care of a retarded ch1ld. Pedlatrics, 1959, 23, 582-584.

KRAMM, ELIZABETH R. Families of mongolold children. Washington, D.C.: U.S. Government Printing Office, 1963.

LLEWELLYN, EVA. Counseling with parents of handicapped children. J. Med. Ass. Alabama, 1962, 31, 329332 .

MCINTIRE, MATILDA S., and KIEKHAEKER, T. C. Parental reaction to a clinic for the evaluation of the mentally retarded. Nebr. Med. J., 1963, 48, 69-73.

MAHONEY, S. C. Observations concerning counseling with parents of mentally retarded children. Amer. J. ment. Def1c., 1958, 63, 81-86. 
MANDELBAUM, $A$, and WHEELER, MARY ELLA. The meaning of a defective child to parents. Soc. Casewk., 1960, $41,360-367$.

MURRAY, M. A. Needs of parents of mentally retarded children. Amer. J. ment. Defic., 1959, 63, 10781088 .

OLSHANSKY, S. Chronic sorrow: a response to having a mentally defective child. Soc. Casewk., 1962, 43, $191-194$.

OWENS, CHARLOTTE. Parent's reactions to defective babies. Amer. J. Nurs., 1964, 64, (11), 83-86.

PATTERSON, LETHA L. SOme pointers for professionals. Children, 1956, 3, 13-17.

RHEINGOLD, HARRIET L. Interpreting mental retardation to parents. J. consult. Psychol., 1945, 9, 142148.

ROBINSON, H. B., and ROBINSON, N. M. The mentally retarded child. New York: McGraw-H1ll Book Co., 1965.

Roos, P. Psychological counseling with parents of retarded children. Ment. Retard., 1963, 1, 345350 .

RYCKMAN, D. B., and HENDERSON, R. A. The meaning of a retarded child for his parents: a focus for counselors. Ment. Retard., 1965, 3 (4), 4-7.

SCHILD, SYLVIA. Counseling with parents of retarded chlldren living at home. Soc. Wk., 1964, 9, 8691 .

- The family of the retarded child. In The mentally retarded child and his family. New York: Brunner/Maze1, Inc., I971, 431-442.

SCHUCMAN, HELEN. Further observations on the psychodynamics of parents of retarded children. Train Sch. Bull., 1963, 60, 70-74.

SHEIMO, S. L. Problems in helping parents of mentally defective and handicapped chlldren. Amer. J. ment. Def1c., 1951, 56, 42-47. 
SOLNIT, A. J., and STARK, MARY H. Mourning and the birth of a defective child. Psychoanal. Stud. Ch1ld., 1961, 16, 523-537.

THURSTON, J.R. Counseling the parents of the severely handicapped. Except. Ch11dren, 1960, 26, 351-354.

TISZA, VERONICA B. Management of the parents of the chronically 111 child. Amer. J. Orthopsychlat., $1962,32,53-59$.

WASKOWITZ, CHARLOTTE H. The parents of retarded children speak for themselves. J.Pediat., 1959, 54 , 319-329.

WATERMAN, J. H. Psychogenic factors in parental acceptance of feebleminded children. Dis. nerv. Syst., 1948, 9, 184-187.

WOLFENSBERGER, W. Counseling parents of the retarded. In Mental retardation, Chicago: Aldine Publishing Co., 1967, 329-400.

ZWERLING, I. Initial counseling of parents with mentaliy retarded children. J.Pediat., 1954, 44, 469-479. 
XIđNA dd 

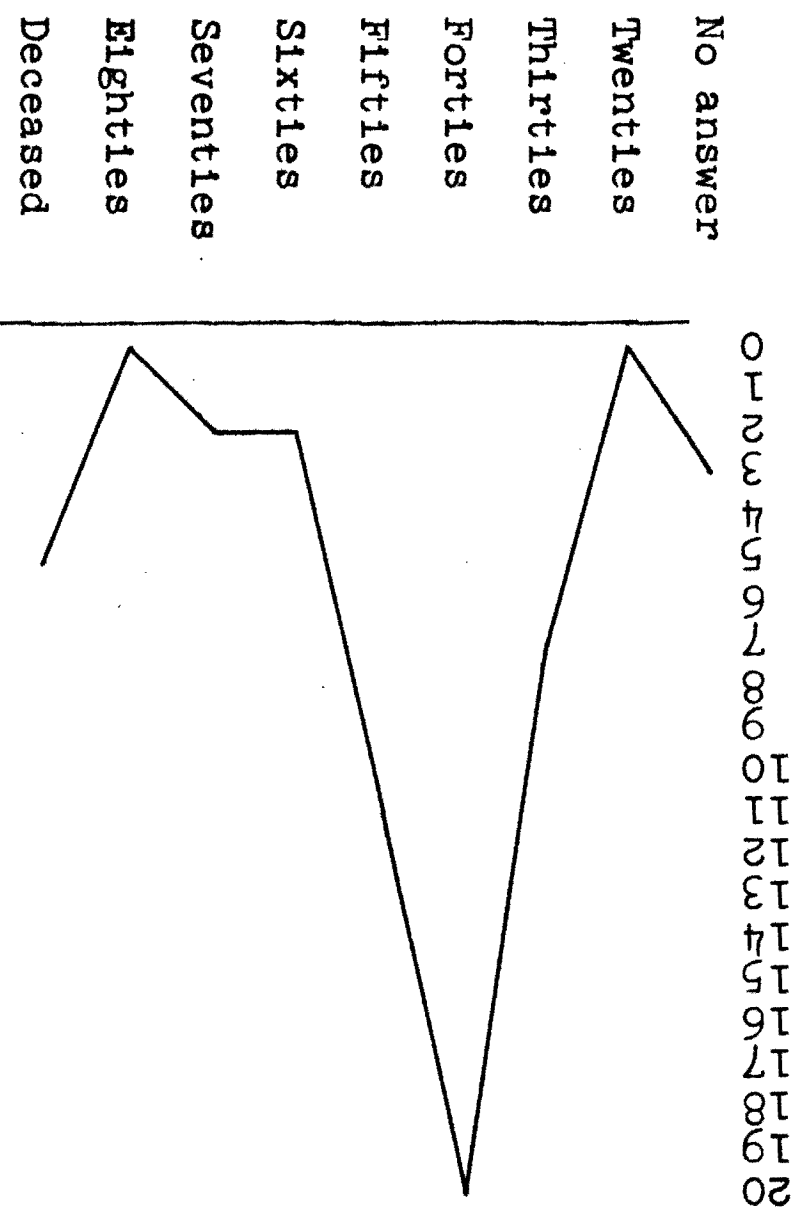

$\overline{\text { GDV , S4GHLVG }}$

T GUกDIA 

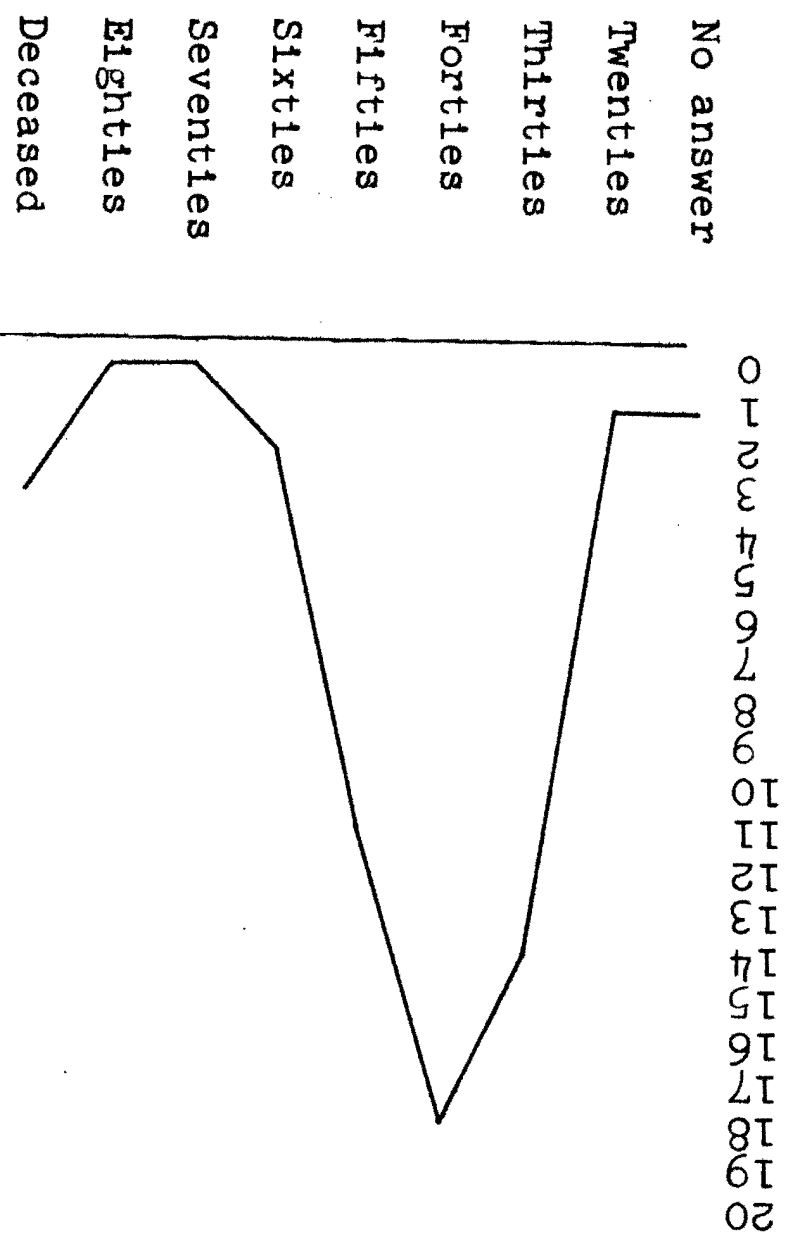

TDV ISYCGHLOW

ट Gप्पกDIA 
FIGURE 3

EDUCATION

Fathers:-- Mothers:---

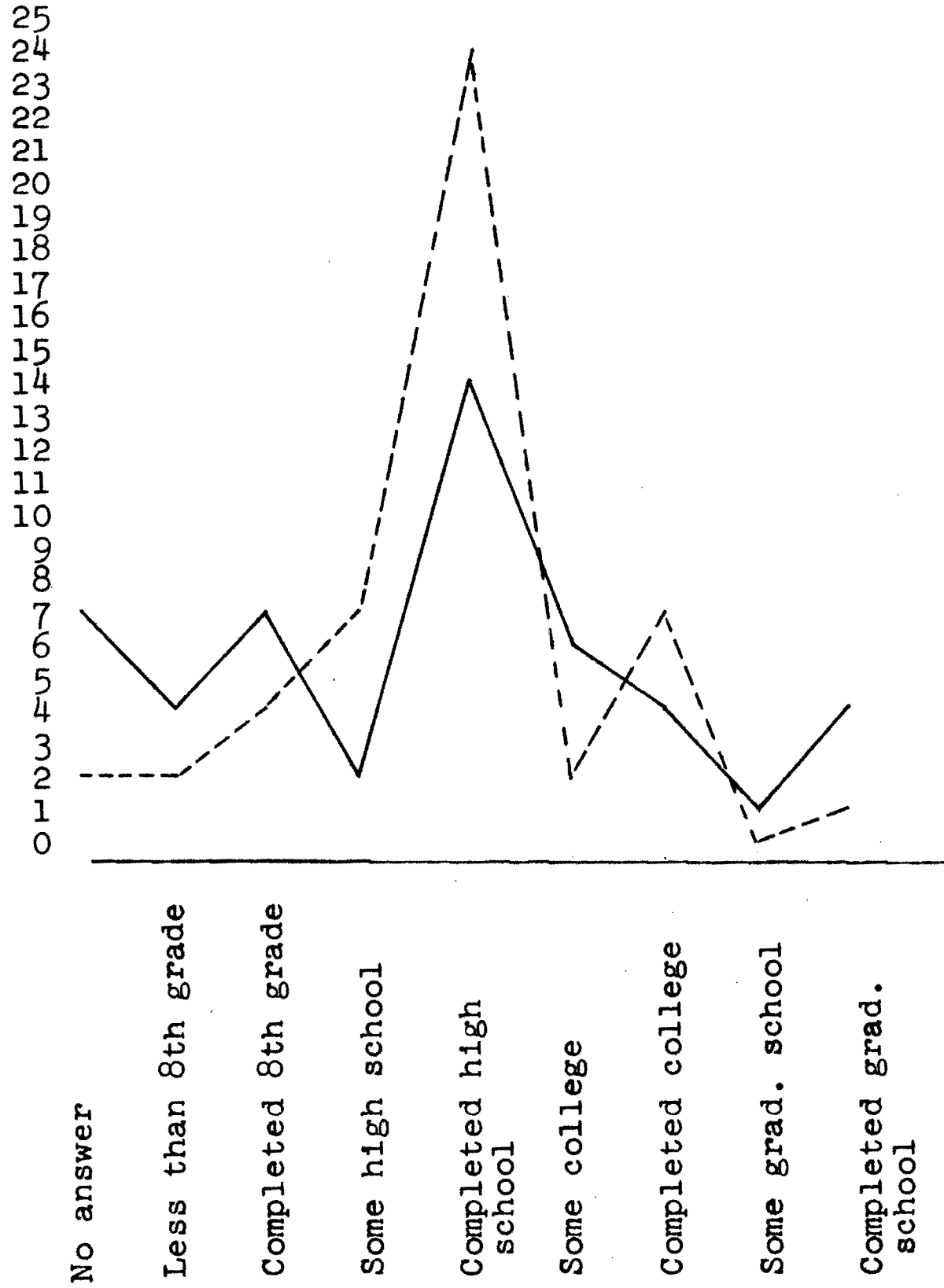



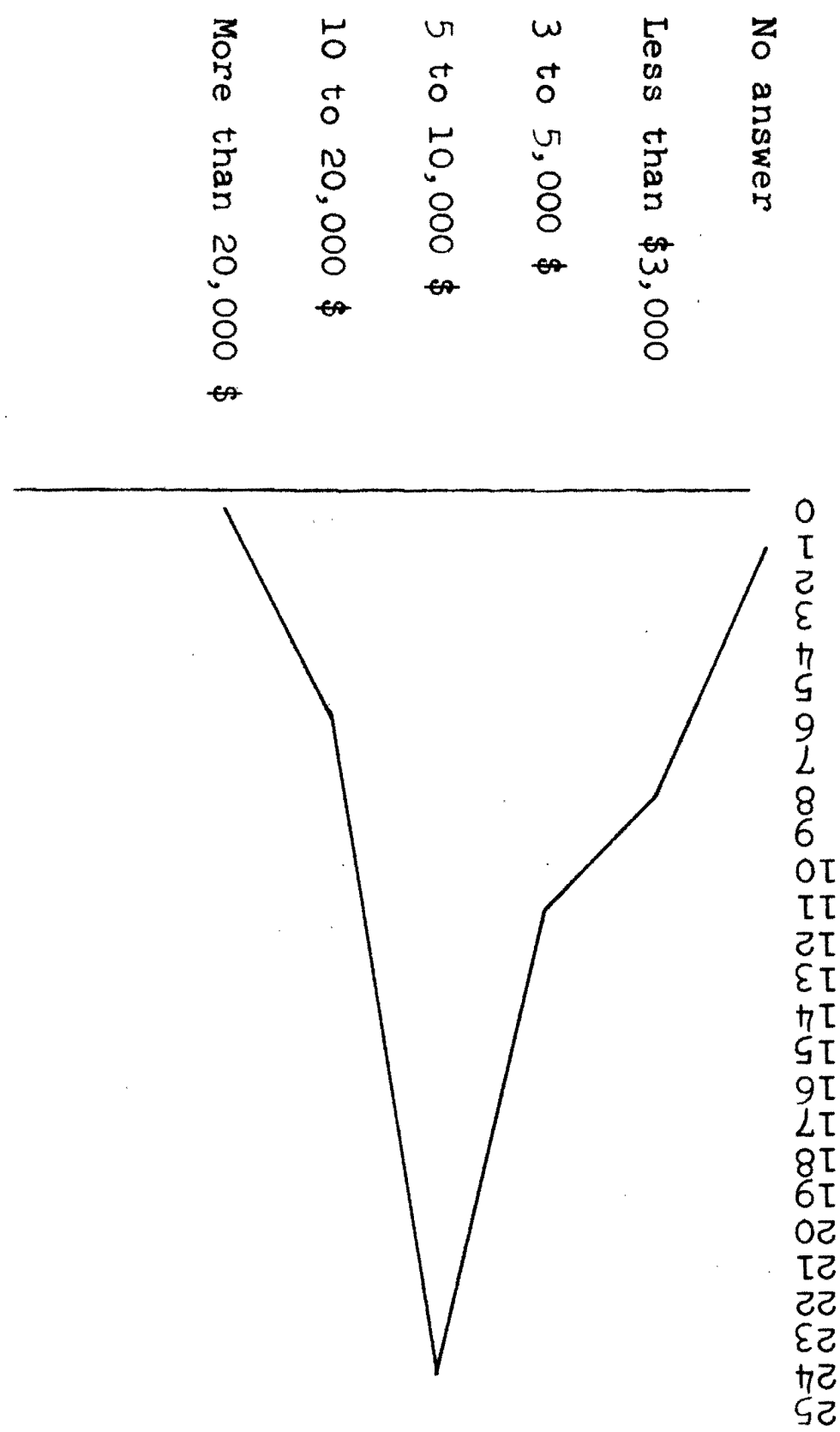

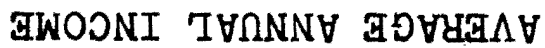

† GHกDIA 
FIGURE 5

\section{LOCATION MOST OF MARRIED LIFE}
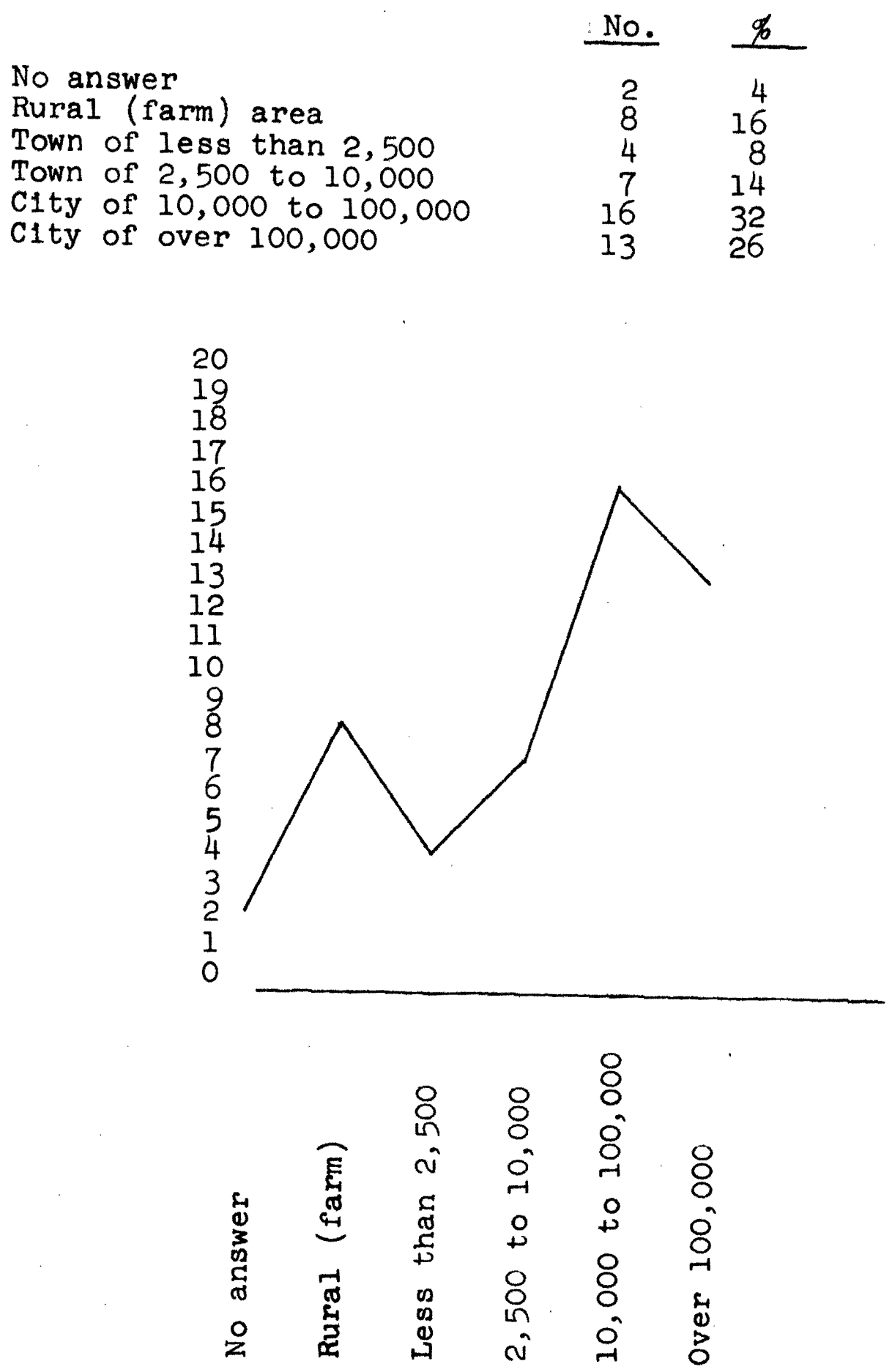
FAMILY INFORMATION

(No Names, Please)

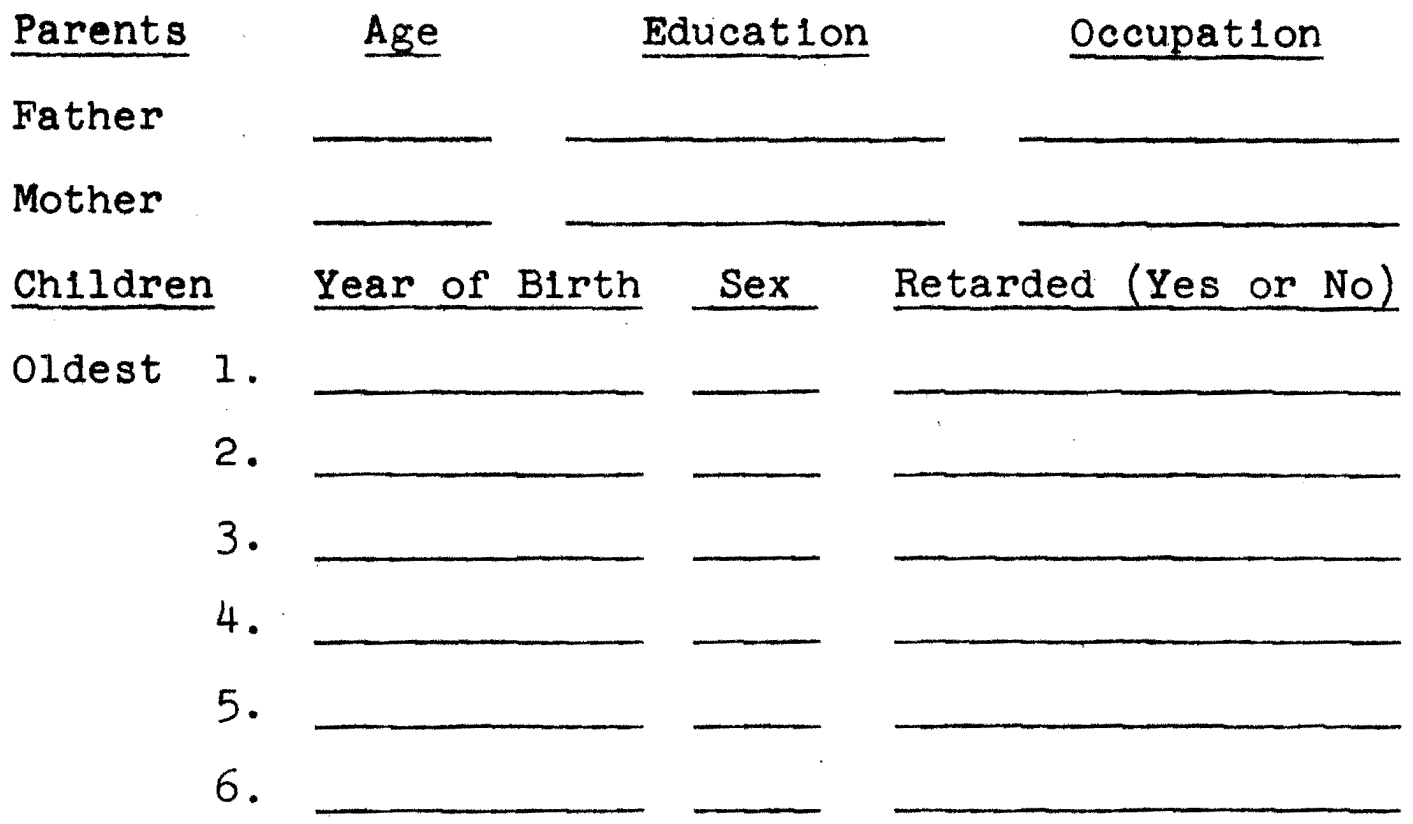

Location

Most of our married 11 fe we have lived in:

a city of over 100,000

a city of 10,000 to

100,000

a town of less

than 2,500

town of 2,500 to

a rural (farm) area

10,000

Income

Our average annual income during the past five years has been:

over $\$ 20,000$ \$3, $\$ 3$ to $\$ 5,000$

$\$ 10,000$ to $\$ 20,000$ less than $\$ 3,000$

$\$ 5,000$ to $\$ 10,000$ 


\section{QUESTIONNAIRE}

1. Where is your retarded child now?

at home and not in any school or work situation IIving and working in a sheltered workshop living outside your home and working in an institution

living in a private boarding school deceased at home and attending a private school for the retarded (for example, Children's Center) at home and attending a public school special education class

at home and working in a sheltered workshop (for example, Goodw1ll Ind.)

at home and working Other (spec1fy)

2. To the best of your knowledge, did your child have any of the following conditions recognized in the first six months of 11 fe?

premature birth

Mongol ism

Hydrocephaly

other (spec1fy)

None of the above as far as I know

3. Did your child "look different" to you at b1rth? yes no 
QUESTIONNAIRE (continued)

4. Did you suspect that your child was retarded before you were told?

yes

no

If your answer to this question is "yes, "for how long did you "suspect" retardation before you were told?

5. How old was your child when you first were told that he was retarded?

6. Who first told you that your child was retarded? (No names, please)

Obstetrician

Pediatrician

Neurologist

Family physician

Psychologist
Social Worker

Teacher

Relative

Friend of the family

__ Other (specify)

7. How did you happen to go to the person who first told you that your child was retarded?

Because of questions of my own

Someone else suggested it

Routine contact (such as school conferences or regular physical examination)

other (specify)

8. What were you told? 
QUESTIONNAIRE (continued)

9. What specific advice were you given at that time about keeping or placing the child?

Place the child in an institution

Keep the chlld through early chlldhood and then place in an institution

Keep the child indefinitely

Go home and think about it

None

other (spec1fy)

10. What degree of retardation have you been told your child has?

educable (borderline)

custodial (severe to

educable (mild)

trainable (moderate) profound)

have not been told

11. Do you agree with what you have been told about your child's retardation?

yes

no

If you checked "no" to the above, which of the following best describes your present bellef?

(this question continued on next page) 
QUESTIONNAIRE (continued)

I think there is really nothing wrong with him. He will be able to get along without all this fuss about special training and the like.

I am sure he will outgrow it some day. He is not as bad as they sald. He could learn if he would only try. He would be all right if he could only learn to talk.

He would be all right if he could only learn to walk.

He would be all right if some one person were able to spend a lot of time with him.

He would be all right if they could only find something that would calm him down.

He would be much better if the schools would just teach him.

He is worse than they said.

Other (specify)

12. Which of the following best describes your memory of your reaction when you were first told that your child was retarded?

I was glad that someone finally told me. I now knew that what I had suspicloned was true. I felt that it was probably true and somehow my f'ault.

I wanted further proof because I doubted that it was true.

I didn't belleve him; I was sure he was wrong. (this question continued on next page) 
QUESTIONNAIRE (continued)

I was so shocked that I didn't know what to think. I didn't realize until later that he had actually told me.

I. was angry.

I just felt sad and miserable.

13. Did you feel that the person who told you that your child was retarded understood how you felt? yes no

14. Do you think more than one appointment is needed for parents to understand the meaning of their child's retardation?

yes no

15. To which of the following did you turn for help and support after being told?

a physician I had known for some time

a physician I had not known before

a social worker

a Psychologist

a Public Health Nurse

a Mental Health Clinic

a school official (such as Principal, Counselor, etc.)

a teacher of the retarded

a relative (what relationship?)

a friend

a Minister, Priest or Rabbi

(this question continued on next page) 
QUESTIONNAIRE (continued)

an institution for the retarded

an association for parents of the retarded

a regular school teacher

No one

God

Books

Other (specify)

16. Which of the following were typical of, or shown by, the person who first told you that your child was retarded:

gave information objectively and factually did most of the talking

gave specific advice

appeared comfortable talking to us

took a lot of time

talked "down" to us

used a lot of big words

expressed sympathy

seemed busy and in a hurry

expressed confidence in us

Impressed us with the serlousness of the situation got us to talk

appeared to understand our problems

gave us encouragement for the future

(this question continued on next page) 
QUESTIONNAIRE (continued)

left the decisions up to us

appeared unconcerned about our feelings

17. Indicate which flve of the following characteristics you would most like to see in a person who must tell a parent of retardation by making a check (X) opposite them in the column headed MOST; also indicate the five characteristics you would least like in a person who must tell a parent of retardation by making checks $(X)$ in the column headed LEAST. Remember, check only the flve most and the five least; do not check the remaining characteristics in either column.

MOST LEAST

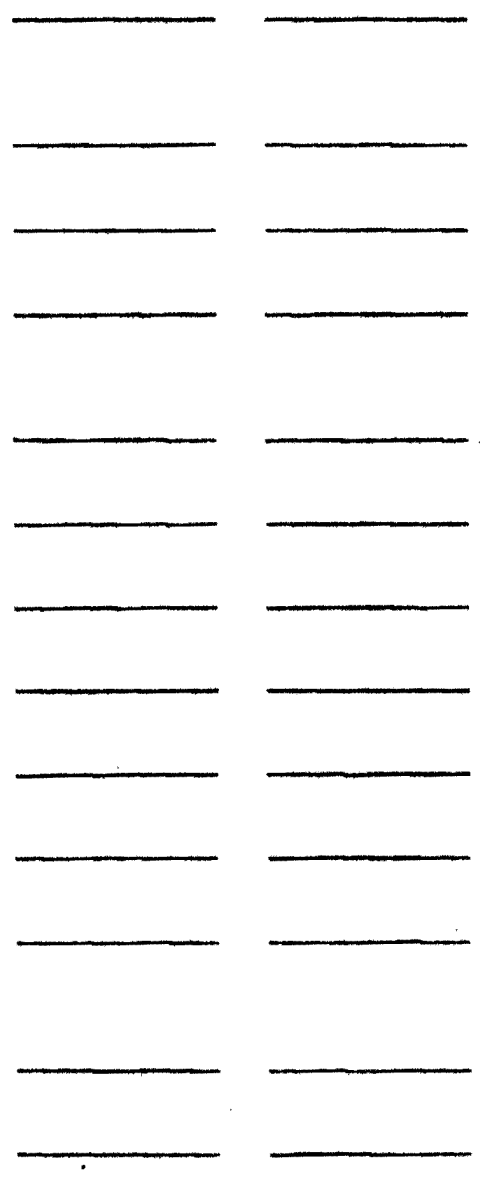

Gives information objectively and factually

Does most of the talking

Gives specific advice

Appears comfortable talking to parents

Takes a lot of time

Talks "down" to parents

Uses a lot of big words

Expresses sympathy

Seems busy and in a hurry

Expresses confidence in us

Impresses parents with the seriousness of the situation

Gets parents to talk

Appears to understand parents' problems

(this question continued on next page) 
QUESTIONNAIRE (continued)

MOST LEAST
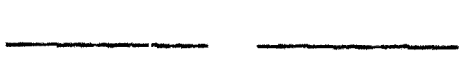

Gives parents encouragement for the future

Leaves the decisions up to the parents

Appears unconcerned about parents' feelings

18. What has been the most meaningful and useful advice you have been given?

Th1s advice was first given by a (no specific names please)

19. What has been the least meaningful and useful advice you have been gIven?

This advice was first given by a

(no speciflc names please) 
QUESTIONNAIRE (continued)

20. What major changes did the knowledge of retardation make in your family?

Brought us closer together

Made us better or stronger persons

Brought us new friends

Brought our feelings out in the open

Made more work for us

Increased our cost of living

Cut down our social IIfe

Upset our other children

Made some of our frlends turn away from us

It put a "wall between us" for a period of time

Made us fearful of having more children

Brought on marital difficulties

other (specify)

21. Please check the two (2) statements from the following list which come closest to describing your attitude toward your child after you were told that he was retarded.

Mother Father

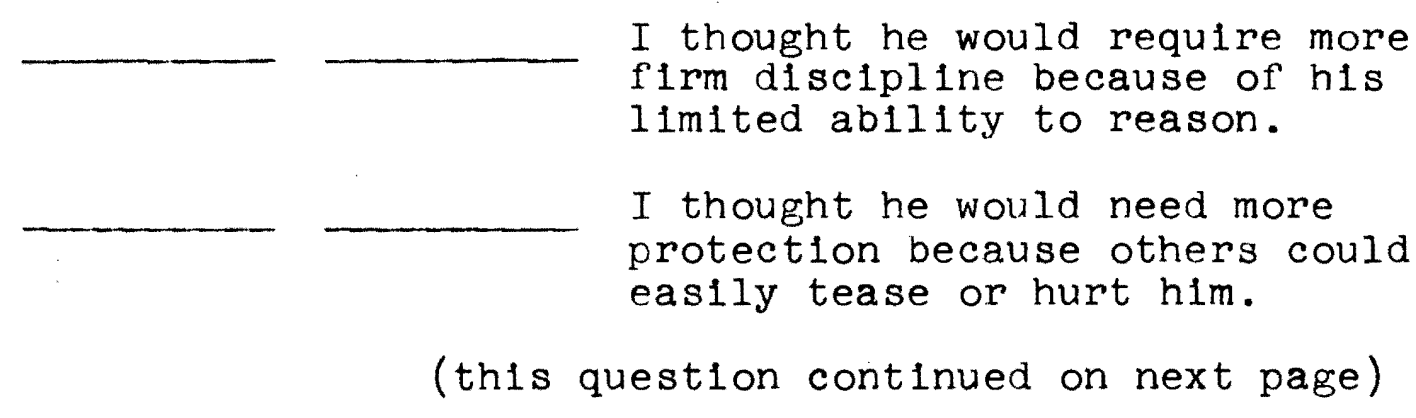


QUESTIONNAIRE (continued)

Mother Father

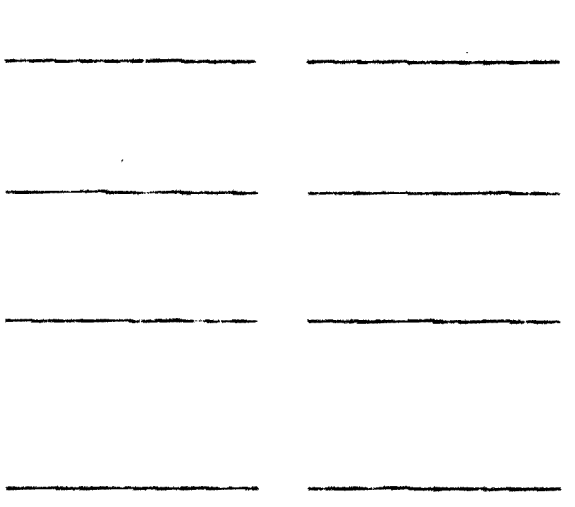

I wanted to "make it up to him" in some way.

I found new interests not related to my child.

I wanted to spend extra time teachirig him in order to prove to others that he could learn.

I reallzed that we would need to make most of his decisions for him.

I felt sorry for $\mathrm{hlm}$ and wanted to give him things he could enjoy.

I thought he could learn so little that I felt useless.

22. Assuming you had the training and had to tell a family for the first time that their child was retarded, which of the following do you think would be the most helpful to them in that first interview?

Advice regarding placing the child outside your home

Advice regarding managing (training) the child at home

Advice regarding school or training facilities in the community

General description of the child's condition without specific advice

Reassurance that it will probably be all right

Sympathy and understanding 
QUESTIONNAIRE (continued)

23. What, in your opinion, are the most important things to be taught physiclans, social workers, psychologists, and educators regarding "telling" parents about retardation? (In your own words)

24. We would appreclate any additional remarks which you think might be helpful to us.

25. Questionnaire completed by Mother

Father

Mother and Father combined

Sometimes there are differences of opinion between the father and mother on many of the questions. If so, please drop us a note and we will be glad to send another Questionnaire so that both opinions can be expressed.

Thank you again for your cooperation. It is through you that we may learn and, having learned, teach others.

Please return the completed form in the enclosed, stamped, self-addressed envelope' as soon as possible.

James Pomeroy, M.D. Superintendent

Falrview Hospital and Training School

Salem, Oregon 